\title{
Marie Davidová \\ Synergy in the systemic approach to architectural performance
}

The integral multi- and cross-layered agencies in eco-systemic generative design processes of the post-anthropocene

\begin{abstract}
This article integrates a series of diverse projects that together exemplify and interpret the Systemic Approach to Architectural Performance (SAAP) that has been developed by the author. SAAP is a fusion of several process-based fields and their media and agency, namely: a) Systems oriented design; b) Performance oriented architecture; 3) Prototypical urban interventions; d) Time-based design; e) Service design; and f) Co-design, co-creation and DIY. The article presents SAAP's relations to these fields and concludes with their integration and synergy in a 'Real Life Co-Design Laboratory', where collaborative and collective processes are seen as the resulting design objects or rather, objectives.
\end{abstract}

Keywords: systemic approach to architectural performance; post-anthropocene; co-design; eco-systemic agency; systems oriented design

\section{Introduction}

Today, environmental science talks about the Anthropocene Extinction, also called the $6^{\text {th }}$ Mass Extinction, which is a current, ongoing event in which a large number of living species are threatened with extinction or are becoming extinct because of environmentally destructive human activities (Wagler, 2017). About $80 \%$ of insects by biomass have disappeared in regions around central and western Europe since the end of the 1980s (Vogel, 2017). A similar pattern is followed by agricultural birds, for example, in Czechia (Czech Ornithologists Association, 2016) and likely in other regions as well. More generally, the Living Planet Report addresses the decline in wildlife populations, shown by the latest Living Planet Index as $60 \%$ in the past 40 years (Grooten \& Almond, 2018). However, humans play full and equal - neither privileged nor pejorative - roles within the overall eco-system and biosphere (Davidová \& Zímová, 2018). Speciesism - the assignment of different moral worth based on species membership - is a psychological construct similar to racism or sexism (Caviola, Everett, \& Faber, 2019). Human world citizens have active and equal roles as co-designers and co-creators of the biosphere, together with other living and non-living agents. However, the appreciation of natural limits regarding what permits humans and the life forms they care about to remain viable includes that humans are part of nature (Burchett, 2014). As Joachim has stated, looking forward to a future that shines is not a platitude but an absolute imperative that empowers designers to speculate about the near future (Joachim, 2015). Since the outstanding characteristic of the biosphere is its inherent ability to sustain life, a sustainable human community must be designed so that its ways of life, technologies, and social institutions honour, support and cooperate with nature's inherent ability to sustain life (Capra, 2005a). 
If the Anthropocene proves more a fleeting geopolitical instant than a slow geological era waves of apes maniacally excavating ancient carbon and drawing loops on maps - then whatever comes 'next' would be formed not by the same anthropos but by something literally post-, un-, in-'human', for better or worse. So too, the cities (Bratton, 2019).

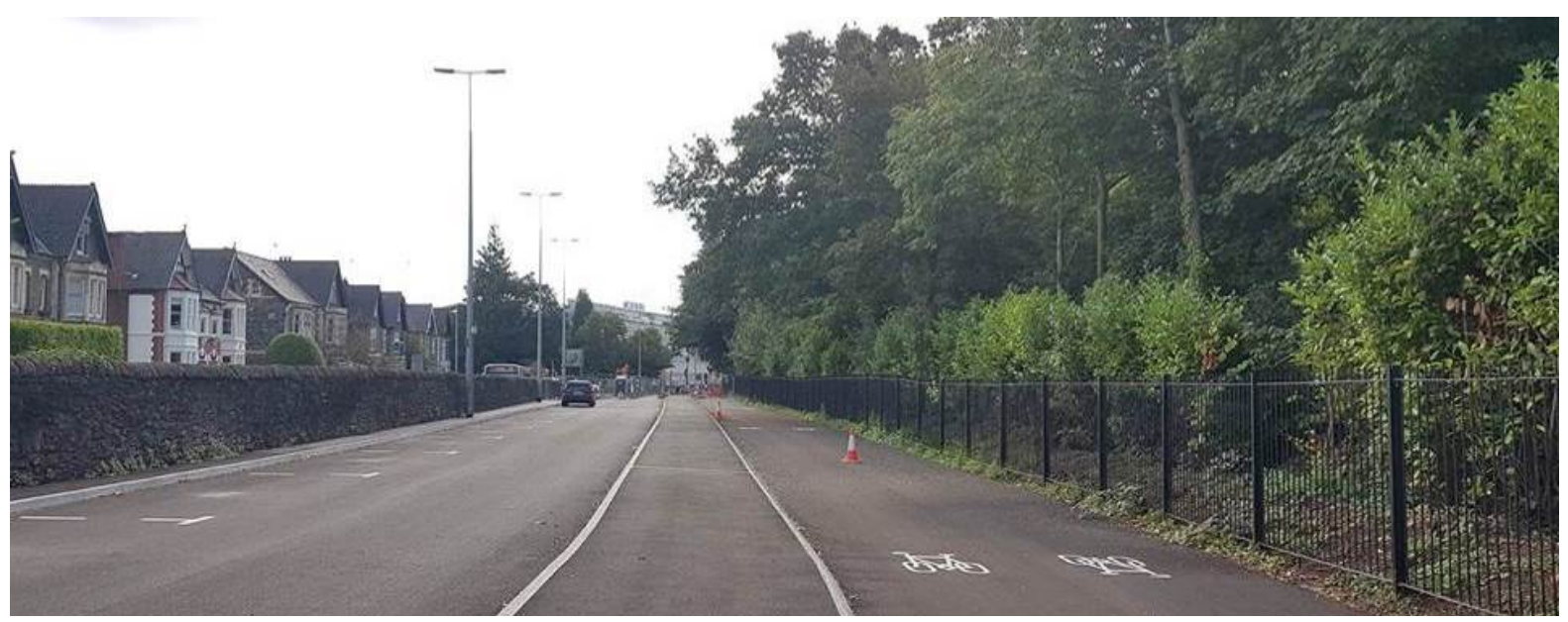

Figure 1: The sharp division of a human built environment and the environment covering other-than human ecosystem in the city centre of Cardiff (Photo: Davidová, 2018).

By integrating several projects presented in previous studies (Davidová, 2017a, 2017b, 2019b; Davidová, Pánek, \& Pánková, 2018; Davidová \& Prokop, 2018; Davidová \& Zímová, 2018), this paper presents the Systemic Approach to Architectural Performance (SAAP) that has been developed by the author in response to above challenges. Bateson states that an aggregate is greater than the sum of its parts because the combining of the parts is not a simple adding but is of the nature of a multiplication or a fractionation, or the creation of a logical product. A momentary gleam of enlightenment (Bateson, 1979). In SAAP, these 'logical products' are collaborative collective processes within landscape, social and cultural ecologies in built and other environments as a way of supporting active living (co-living) and performance (coperformance) within or across eco-systems. In so doing, SAAP addresses the co-activation of a shift from the Anthropocene towards support for biodiversity and adaptation to climate change in the co-generation of natural, cultural and technological fabric by humans and nonhumans. Generally, the prefix co- in this field is used either for collaborative, collective or both, and is crucial because we need to flourish in this world together. SAAP, therefore, represents a holistic, synergetic approach conceived as a rea life co-design laboratory, which, as opposed to the concept of a traditional modernist laboratory, engages with the complexity of real life in real time (Davidová et al., 2018). This concept evolved from Sevaldson's concept of rich design research space (Sevaldson, 2008). It integrates the real life performance of, and within, the eco-system of the built environment. These two concepts previously tended to be thought as distinguished (see Figure 1; Davidová \& Raková, 2018; Davidová \& Zímová, 2018; Hensel, 2019). This distinction still represents the prevailing tendencies of current urbanism and urban design. However, such tendencies are in opposition to current landscape ecology. The present work, therefore, claims that these fields require an integral approach across the living eco-system with all. The idea of real-world laboratories or real-world experiments have already met commercial architectural practice through full-scale prototyping, such as the Helen \& Hard studio in Stavanger, Norway (Stangeland, 2018). These processes, however, result in final-end product solutions and, as such, are result-oriented (Bernert, Haaser, Kühl, \& Schaal, 2016). This result oriented approach blocks all the co- and re-designing processes at the 
moment when the concluded proposal starts meeting the real life (Davidová, 2019a). These approaches can be distinguished from where the 'results' or outcomes of co-design processes continue in co-performance with the real life physical, social, cultural and natural environment 1 in time. This also suggests that this co-performance is appearing within bio-digital environments, where the term bio-digital stands for the synergy of digital technologies with biological matter and agency and is understood as one of the typical attributes of the postdigital era. The real life full-scale bio-digital (i.e. post-digital) eco-systemic prototyping (Davidová, 2019b) tends to be conducted through not-for-profit associations or projects (NGOs or others) in collaboration with the academy, and targets education by providing knowledge and skills to future generations of architects, with current practices as well as to other makers (Davidová \& Sevaldson, 2016b, 2016a; Joachim, 2019; Moxon, Moxon, \& Cougill, 2018). Here this prototyping targets diverse communities through marking the prototypes in real life co-design laboratories with QR codes. These concepts lead to codes and recipes for 'do it yourself' (DIY) activities to generate locally specific adaptations (Davidová, 2019b; Davidová \& Zímová, 2018).

From the ecological theory point of view concerning design, time-based richness has been discussed by Boehnert. She notes that ecological theorists suggest that humankind's current environmental problems result from a highly reductive way of knowing and an intellectual tradition characterised by atomism, mechanism, anthropocentrism, rationalism, individualism and a dualistic tradition that pits humanity against the non-human natural world. She also notes that such an attitude to sustainability built on simple fixes is pure greenwashing, rather than a sustainable solution achieved through ecological literacy, the learning of which is achieved through capacity-building, enactment and transformative practice (Boehnert, 2015). Thackara pointed out that the design of connections between places, communities, and nature is already widespread, and accelerating (Thackara, 2015). Moreover, these new undertakings may be diverse, but a green thread connects them: the understanding that caring for the health of a place and of the persons who inhabit it are parts of one story. With this care for place as their frame, communities are connecting the 'what is' with the 'what if?' across a range of activities, including regional food hubs, High Nature Value farming, fibershed and grain chains, biorefining, forest and watershed recovery, land-based learning, code clubs and the maker movement (Thackara, 2019).

As opposed to the classical paradigms that tend to emphasise clarity and unified integrity as self-evident necessities, the premises of classical rhetoric have tended to create polarised divisions between interior and exterior spaces, between human beings and things, and between the realms of technology and nature (Beesley, 2019). This article follows the attempts and manifestations of the Living Architecture Group (Beesley, 2019) in a search for synergy and integral processes of the living and non-living, human and non-human, natural and 'artificial' co-performative eco-systems and biospheres. The research realises that our health, well-being and, ultimately, survival depends on working with, not against, natural forces (Boehnert, 2015). These forces also include humans that are fully integrated into the coprocesses of the entire biosphere. This article exemplifies these synergised processes on several bottom-up iterative 'responsive wood' (Hensel \& Menges, 2006) projects that form the SAAP.

\section{The synergising integrated process-based fields}

The SAAP synergises, integrates and reinterprets several process-based fields for eco-systemic real time live co-performance in living environments. Though the history of performance has a larger background (Hensel, 2013), the understanding of a shift to performance in architecture in the context discussed, explicitly appeared in 2001 when Stan Allen reformulated the question of what is architecture to what architecture can actually do (S. Allen, 2011). This notion was further reformulated by Hensel as "a driving concept for design that helps re-consolidate form and function into a synergetic relation with the dynamics of natural, cultural and social environments" (Hensel, 2010). The framework of SAAP, as introduced here, does not only 
discuss the architectures' active agency but also its active, systemic, generative and iterative co-engagement within the synergised natural, cultural, social and political environment, synthesising living and non-living, biological and technological fields. This synergising process occurs within the eco-system with which it cross-interacts and with which it co-creates, co-generates and co-lives.

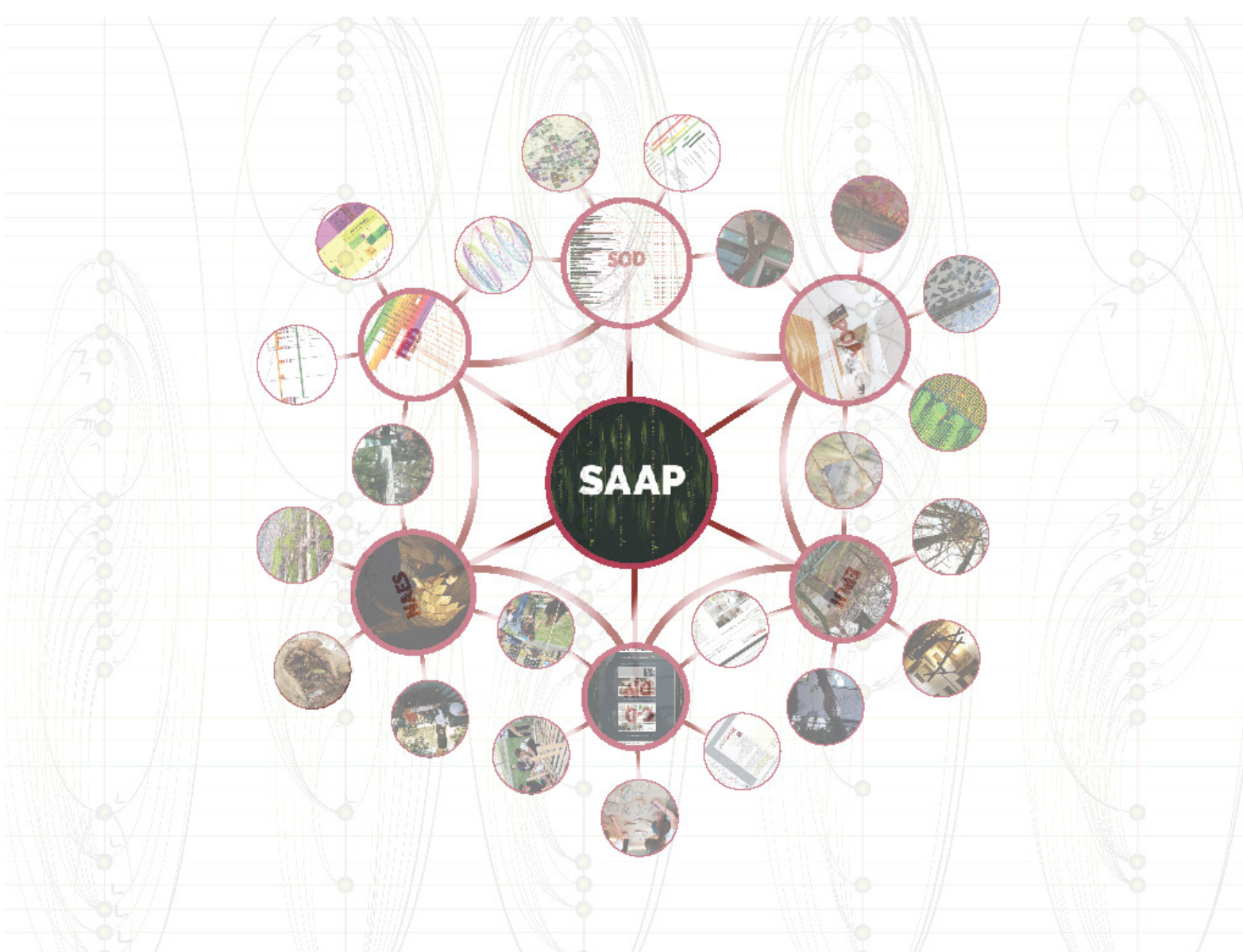

Figure 2: Synergised integrated process-based fields of SAAP (Diagram: Davidová, 2019).

However, real life architectural practice approaches face serious opposition and obstructions when it comes to architectural schools' curricula as well as building laws and regulations on national and regional levels. The reason is because such systems are built as result-oriented and focused on single reductionist measures of outputs, as opposed to modernist object-based problem solving when designing for- instead of with-. Sanders and Stappers state that over the past 30 years, almost every aspect of doing design has changed (compared to the times when the curricula and building laws were grounded). We still seem to be in the middle of a transition to greater entanglement and complexity, but with greater involvement of people and, hopefully, more value contributed by the design capabilities of many (Sanders \& Stappers, 2014). The 'many' for the author means more than people. Therefore, SAAP is realising these transitions and searches for a synergy of multiple processes in the real-life age of the Post-Anthropocene. The key fields discussed in this body text are as follows: 1) Systems oriented design (SOD); 2) Performance oriented architecture (POA); 3) Eco-systemic prototypical urban interventions; 4) Time-based design; 5) Non-anthropocentric eco-systemic - service design, and 6) Co-design, Co-creation and DIY (see Figure 2). 
SAAP contributes to this broad range of co-creating fields by opening diverse media to, in particular, biotic ${ }^{2}$ and abiotic $^{3}$, living and non-living agency through hands-on, active co-design participation ${ }^{4}$ in real time and life. The generative agency is here understood as co-creative cross-interaction that co-designs evolutive performance. Its media involve the following: a) the complexity diagramming - a manual analogue and a digital tool from SOD called gigamapping, the most designerly way to deal with systems (Sevaldson, 2013); b) digital and analogue modelling; c) full-scale prototyping; and d) the integral co-performances and cross-interactions of all the above mentioned, ${ }^{5}$ generated in real time. While Meadows argued that although systems cannot be controlled, they can be designed and re-designed (Meadows, 2002), in this view, the designers' role is not to redesign an (eco)system ${ }^{6}$ but to maintain their dialogical interaction with it. Such a statement implies a shift from conventional approaches to the architectural profession that believes in the full authorship of the $\operatorname{architect(s)}$ and her/his/their final product that needs to be kept inviolable. Through the discussed dialogical interaction, one can take an active role in its co-design and, therefore, generatively co-redesign the (eco)system and potentially the biosphere ${ }^{7}$ or even more. This situation occurs because of the interdependence when, together, plants, animals, and microorganisms regulate the entire biosphere and maintain the conditions conductive to life (Capra, 2005b).

The active agencies within the co-design are, at the same time, their creative design tools. They (the agencies) involve creative trans-disciplinary and trans-social, trans-biological, material, climatic, mechanical or bio-digital and digital performances. These goals are achieved through eco-systemic prototypical urban interventions (Doherty, 2005), established as generative time-based urban design tools with minimal interventional input into an urban fabric at the start of the millennium by the CHORA office (CHORA, 2017). Within this construct, SAAP also integrates information from hands-on studies from historical references that were tested and developed over generations. Through these informed generative interventions, the projects are co-creating eco-systemic services in the built environment. This co-creation is supported by another layer of generative co-designing agency that stimulates communities to create DIY iterations.

\section{Systems oriented design}

SOD looks beyond objects to access a 'rich picture' (Checkland, 2000) of complexity serving as a generative design tool. SOD looks holistically at vast fields of relations and patterns of interactions (Sevaldson, 2013). SOD is framed in a rich design research space, which takes into account physical, social and cultural spaces, and the virtual and visual media in which the research-by-design takes place (Sevaldson, 2008). In SAAP, this process based space takes place in the public space of the building site (see Figure 3) or in adjacent, publicly accessible refreshment spaces (see Figure 4 and Figure 5), allowing for more than just visual stimuli, accompanied by social events, such as EnviroCity Festivals, that increase attention and engagement (see Figure 5). These kinds of rich design research spaces are called real life codesign laboratories that are in direct confrontation and interaction with real life on site. Such spaces or laboratories cover real time co-design with living and non-living, human and nonhuman communities and diverse trans-disciplinary team members and stakeholders.

Diverse actors in this kind of rich design research space require diverse media. For example, within human speculative co-design, some disciplines or public relate better to drawing or images, others to physical or digital modelling, prototyping or combinations of all (see Figure 3 and Figure 4). The critical role of such discussed diverse media is to represent a role of what Jabi calls the 'artifacts' that are used to communicate design intention in collaborative design (Jabi, 1998). This process needs to be, at the first point, grounded within physical gigamapping to find the relations of the natural, social and cultural data, thoughts, collective understandings and speculations. The physical maps can be further translated to digital maps and digital modelling simulations in repetitive feedback loops, being printed and fabricated to meet cross-species and cross-forces dialogical interaction all over again (see 
Figure 5 and Figure 6). It is important to note that, in SAAP, interactive feedback is simultaneously co-designed with multiple kinds of agency. The prototype's performance is cogenerated by, e.g. relative humidity, temperature, their material properties and organisms that appear in its adjacent environment or directly settles on or in the prototypes (see Figure 7). Therefore, SAAP involves a sort of 'mangling' with material agency that can be seen as a realm of instruments, devices, machines, and substances that real time act, perform and do things in the material world, as suggested by Pickering. However, this agency is not seen goal-less to the other types as opposed to Pickering's interpretation (Pickering, 1993). Therefore, the design processes in SAAP appear to be cross- and multi-layered with these multiple agencies and mixing digital with analogue, human with non-human, biotic with abiotic, living with nonliving in a real time search of synergy. This co-performance occurs in a rea life co-design laboratory.

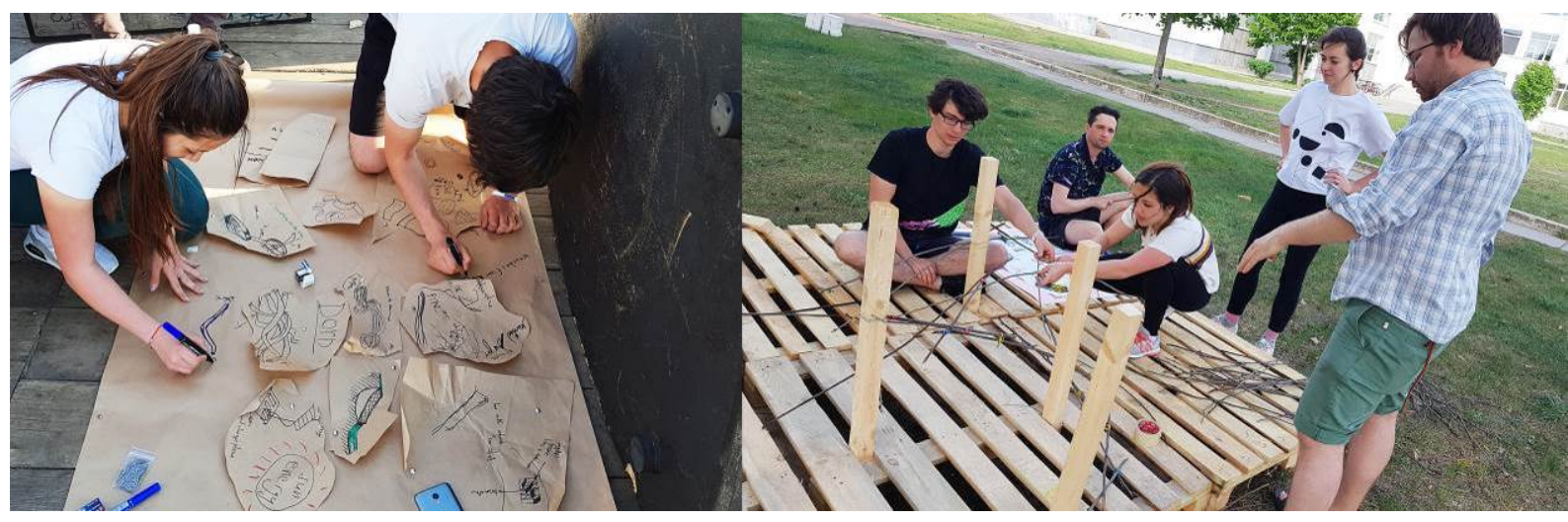

Figure 3: Rich Design Research Public Space with gigamapping and conceptual modelling on a building site targeting community co-design of Co-oCo-oNest project in Slavutych, Ukraine (Photo: Davidová, 2018).

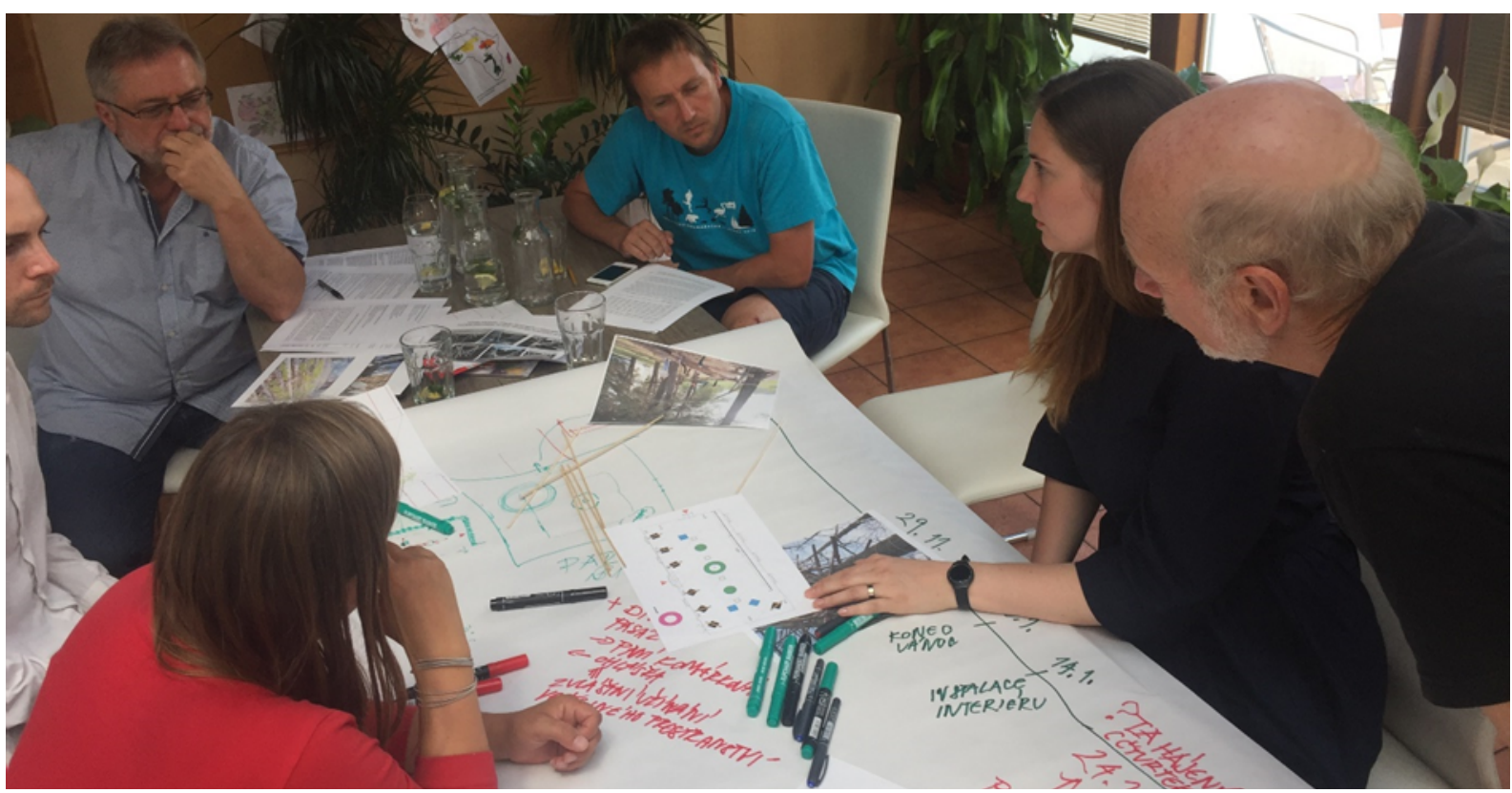

Figure 4: COLridor II Project Rich Design Research Space in a local restaurant covering stakeholders' gigamapping that uses sketching, work with referential images and conceptual model-making (Photo: Gönulf, 2018). 

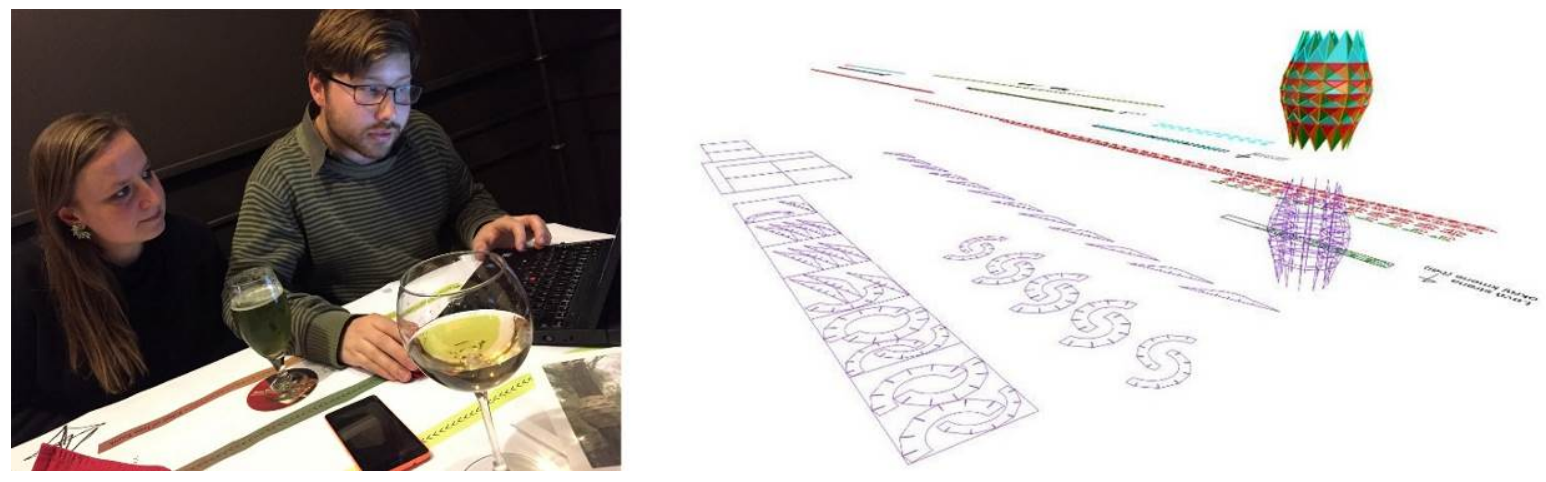

Figure 5: Combining gigamapping and computing while co-designing with the local community and trans-disciplinary team in project COLridor I (Photo: Zímová, digital model, and print screen: Prokop, 2017).

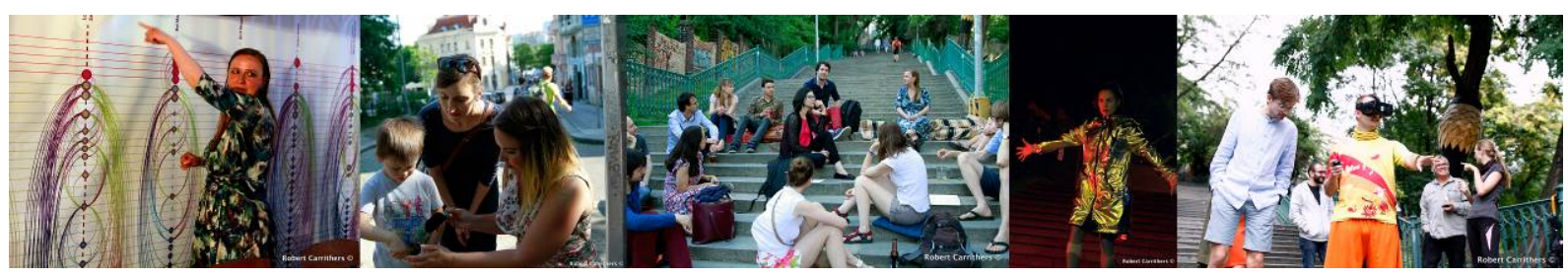

Figure 6: Selection of the events of the EnviroCity 2017 festival for COLridor I project (Photos: Carrithers, 2017).

\section{Performance oriented architecture}

POA was suggested by Hensel as non-anthropocentric, requiring the integration of core concepts in architecture and biology. This notion informs the integrated spatial and material organisation of architecture and its interaction with the physical environments towards the production of heterogeneous provisions that can help sustain ecosystems and biodiversity (Hensel, 2012). SAAP cases have mainly focused on developing and applying nonanthropocentric and responsive solid wood concepts through full-scale prototypes in built and other cultural environments by exploring such a framework. These projects have investigated the hygroscopic co-performance of living and non-living biological matter and agency (i.e. wood and algae), synergised mainly with the abiotic agency of micro-climates and biotic transition paths of bio-corridors (see Figure 7 and Figure 8). These prototypes take direct, active engagement within their natural, social and cultural environments, co-performing and co-designing their edible, habitable, transferable, exchangeable and micro-climatic ecosystemic services (see Figure 9). For example, the responsive envelopes Ray warp as the relative humidity decreases with increases of the temperature while being sorped by algae colonies on them to which they enable suitable living conditions (see Figure 7). In the COLridor II project (see Figure 8), the hygroscopic wooden installation enables life for early blooming nectar producing plants in an otherwise fully built area. The TreeHugger projects (see Figure 9 and Figure 10) apply the responsive screen Ray to generate suitable climatic dwelling chambers for a variety of insect species, thus also generating edible landscapes for bats and birds. Therefore, based on the observations of investigated research by co-design case studies $^{8}$, it is apparent that SAAP adds to the discussion on performance its time-based generativeness and extended real time participation in co-creation, that is, a co-performance within the real life co-design laboratory. Therefore, SAAP integrates POA as well as adding to it. 


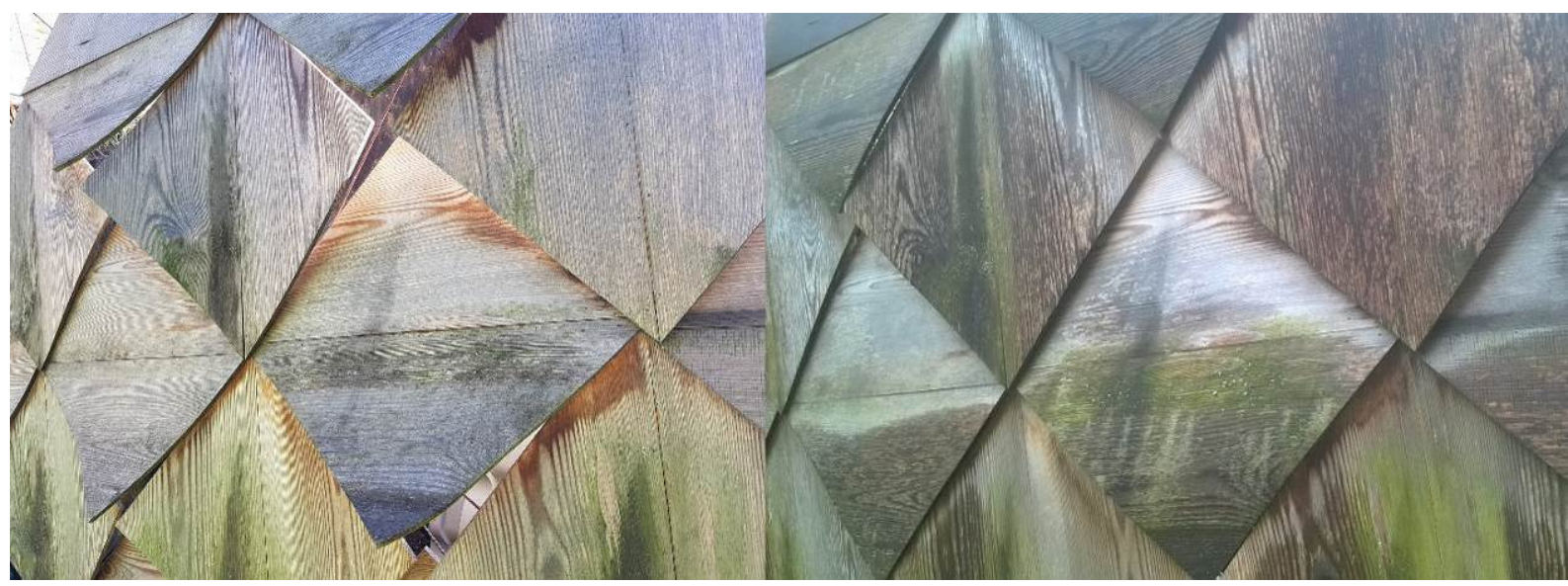

Figure 7: Ray 2*2013 Responsive Wood Envelope Prototype: a) in semi-dry June 2018 weather when the screen is open for boundary exchanges between exterior and semi-interior; $b$ ) after light rain in April 2017 when the system is closed, which does not allow the humid and cold air to pass through the boundary after five and four years, respectively, of exposure to weather and biotic conditions (Photos: Davidová, 2017 - 2018).

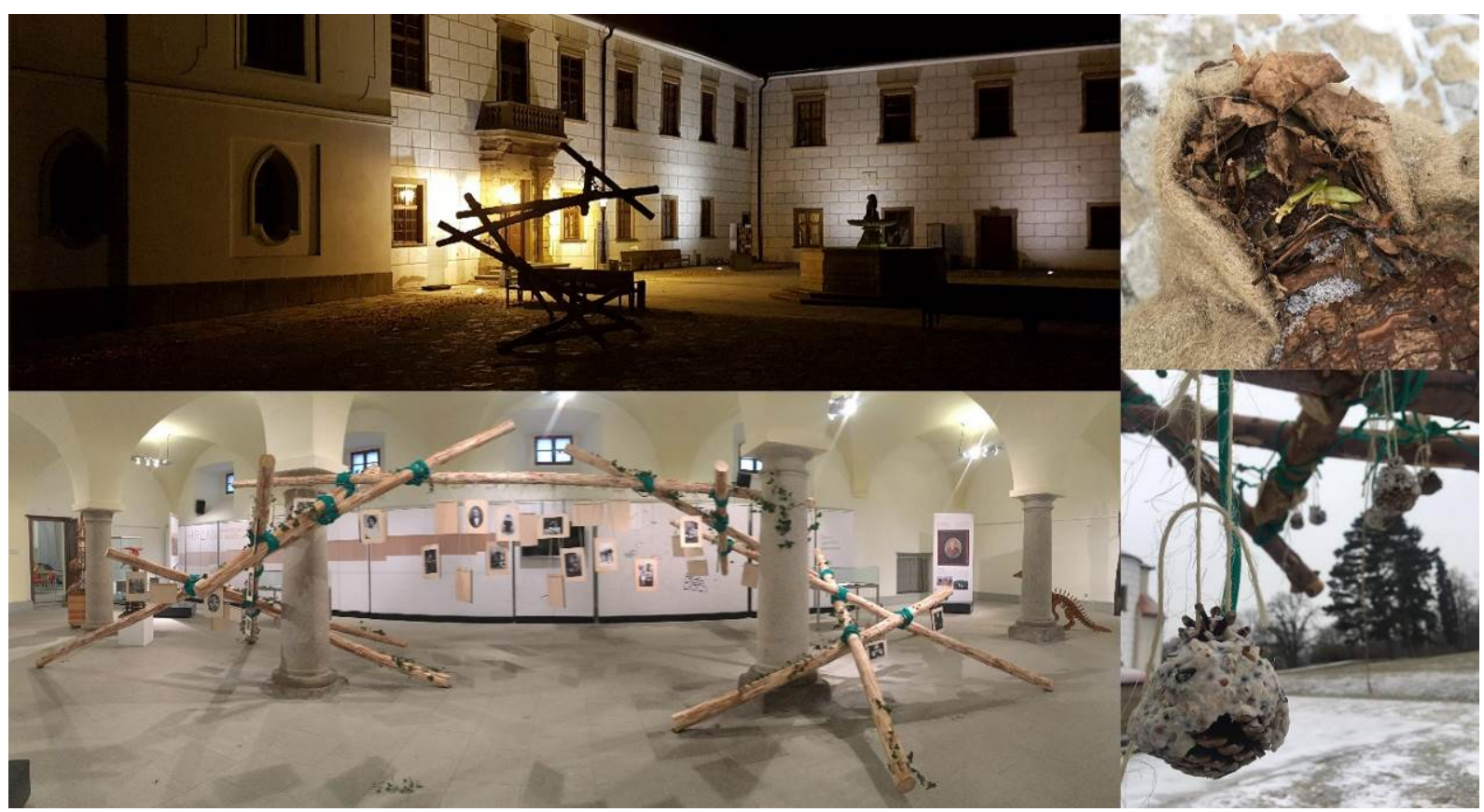

Figure 8: A COLridor II project built as an architectural solution by the Collaborative Collective for Czech National Heritage Association's exhibition on wood-building constructors' lineage Herzán family (photos: Davidová 2018 and Zímová 2019).

\section{Eco-systemic prototypical urban interventions}

From an urban and landscape perspective, Doherty (2005) explains prototypes as architectural and programmatic interventions open to changing political, economic, ecological and social dynamics over time and space. The prototypes present a more strategic, canny and fluid approach rather than determinate strategies like master planning. Prototypes perform with uncertainty by creating and maintaining a spatial dialogue of sorts over time (Doherty, 2005). In other words, prototypes act as a generative force that is in dialogic co-engagement with its surrounding environment. Therefore, with the bottom-up approach of rather small and simple 
inputs, the prototypes can grow into an expansive and complex time-based output. The prototypes in SAAP have a non-anthropocentric nature and focus on the engagement with the overall eco-system through its (eco)systemic interactions, targeting on taking part in (eco)systemic co-re-design through co-design. Therefore, these prototypes are called ecosystemic prototypical urban interventions. They interact and engage with food webs; transfers and exchange of nutrients, genetic, biological, biotic as well as abiotic, living and non-living material, cross-species cultural, social and political systems and agencies; co-habitats and codwellings, and so on (see Figure 8, Figure 9 and Figure 10) ${ }^{9}$. Therefore, such interventions engage the eco-systems to co-perform and co-generate through engaging actions that are caused by rather small physical invasions by items into the environment.

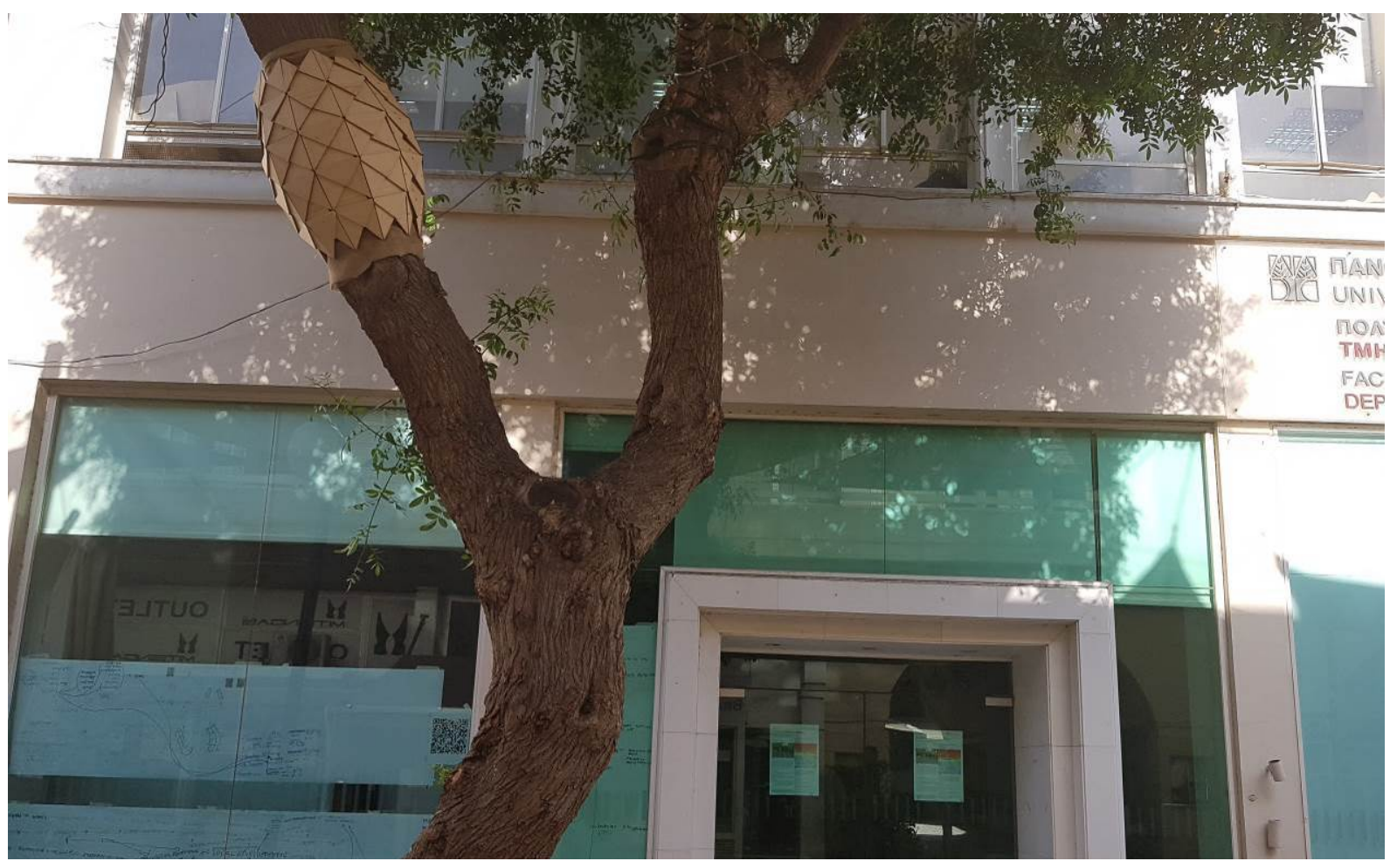

Figure 9: TreeHugger $C Y$, together with exhibited design gigamaps and $Q R$ codes leading to the SAAP blog with a recipe for its creation and generating its iterations (Photo: Davidová, 2018).

\section{Time-based design}

The direction of the media mix and time-based design was suggested by Sevaldson (2005) regarding creative digital design techniques (Sevaldson, 2005). Sevaldson explains the framework of developing time-based projects as a) observation, b) analyses, and c) intervention. The explained observations develop along several paths: 1) movement in the spirit of Marey's experiments (Braun, 1992); 2) the performance of singular objects with emphasis on relations to other objects or environments over time; 3 ) a complex situation with emphasis on the discovery and analyses of patterns in the interaction between entities and environments' (Sevaldson, 2004). SAAP intersects these layers and feedback with looping stages and paths over time. SAAP's processes are adaptable in a way similar to 'Transition Design' in that they involve several processes, such as machine learning (Irwin, 2015). Nevertheless, in SAAP, these processes happen both bio- and socio-organically. The interventions are not seen as a final object but as a performing generative input and drive for co-design and co-living that will be further observed, analysed, inhabited, eaten, iterated, compared with other inputs, and of course co-re-designed (see Figure 10 and Figure 19) ${ }^{10}$. 


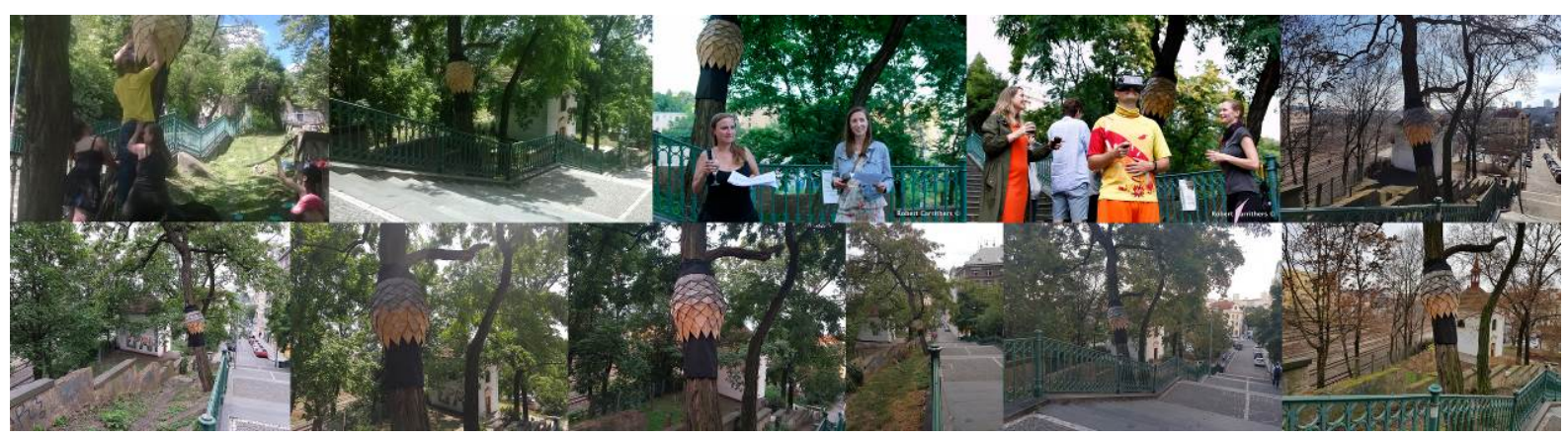

Figure 10: TreeHugger CZ performing over time from being built in spring 2017 to winter 2019. Please note the inhabitation by algae after autumn 2017 (Photos: Davidová and Carrithers, 2017 - 2019).

SAAP also covers the analysis of time-based historical prototypes that were developed, tested and rebuilt with add-on layers and a variety of adaptations over generations. The ecosystemic performance is apparent mainly in architectures from extreme climates (Davidová, 2016b), where the cross-species co-living situation seems to be more crucial (Davidová \& Raková, 2018; Davidová \& Uygan, 2017) (see Figure 11). ${ }^{11}$ Many indigenous and traditional examples, in contrast to current civil engineering, offer opportunistic co-habitation possibilities as we know them from nature (see Figure 13). Some features seem to be useless unless someone engages with the opportunity they offer (see Figure 12). Such observations show that climatic, political, cultural, social, technological and natural systems are time-based and in need for continuous cross-referenced co-adaptation, though many of those systems operate in very different time frames.

Within the performance field, the pioneering work in this context is addressed by Hasan Fathy, with a focus on the abiotic micro-climatic performance of traditional architectures in arid climates (Fathy, 1986). The biotic performance investigation was added and developed by Hensel and Sunguroğlu Hensel (2015). The latter has, however, focused purely on speculative computer simulations or theories. SAAP has investigated such complexities through hands-on real life experience through traditional and indigenous architecture studies in Norway, Cappadocia and elsewhere (see Figure 11, Figure 12, Figure 23, Figure 24 and Figure 25; Davidová, 2016b, 2018; Davidová \& Rakova, 2018; Davidová \& Uygan, 2017) and hands-on real life contemporary applications over time through the above-discussed prototypes. These hands on studies are the crucial contribution material to this emerging research by the design field of SAAP.

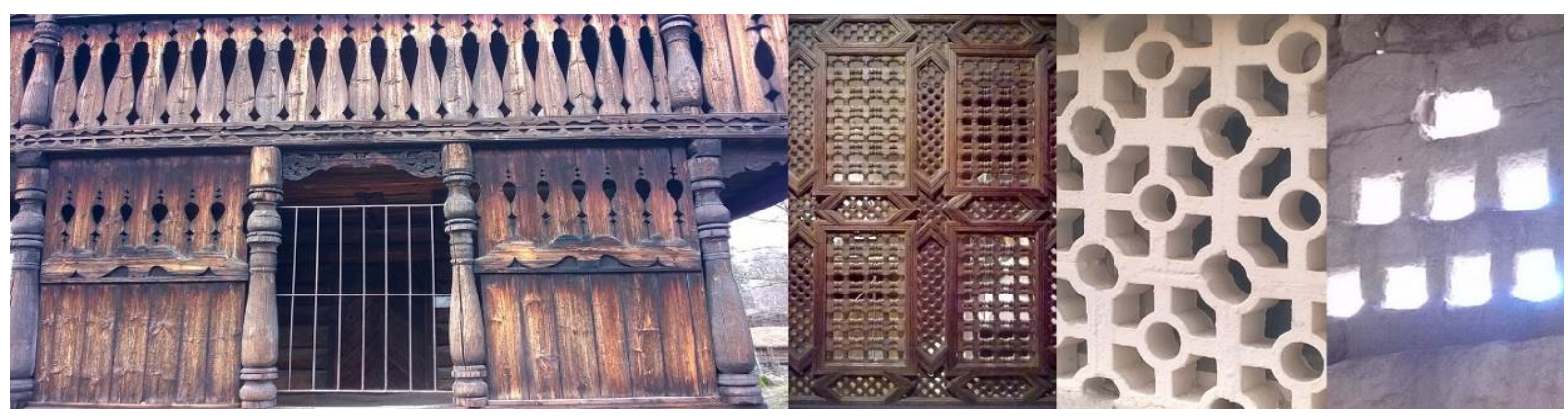

Figure 11: 'Breathing Walls' in vernacular architecture: from left to right, a) Norwegian svalgang (a semiinterior space) screen of a habitable loft from 1797, Oslo Open Air Museum, Norway (Photo: Davidová, 2016); b) Moroccan mashrabīya separating different climatic and privacy layers of the onion principle of a traditional Turkish house from about the 15th century, Houston Museum of Fine Art, USA (Photo: Davidová, 2016); c) traditional south Portugal screen wall in Fishermen's Village, Salema, generating a semi-interior micro-climate between a street, a courtyard and a house, Portugal (Photo: Davidová, 2016); d) Çavuşin Monastery's human-pigeon house from 964/5, Cappadocia, Turkey (Photo: Davidová, 2016). 


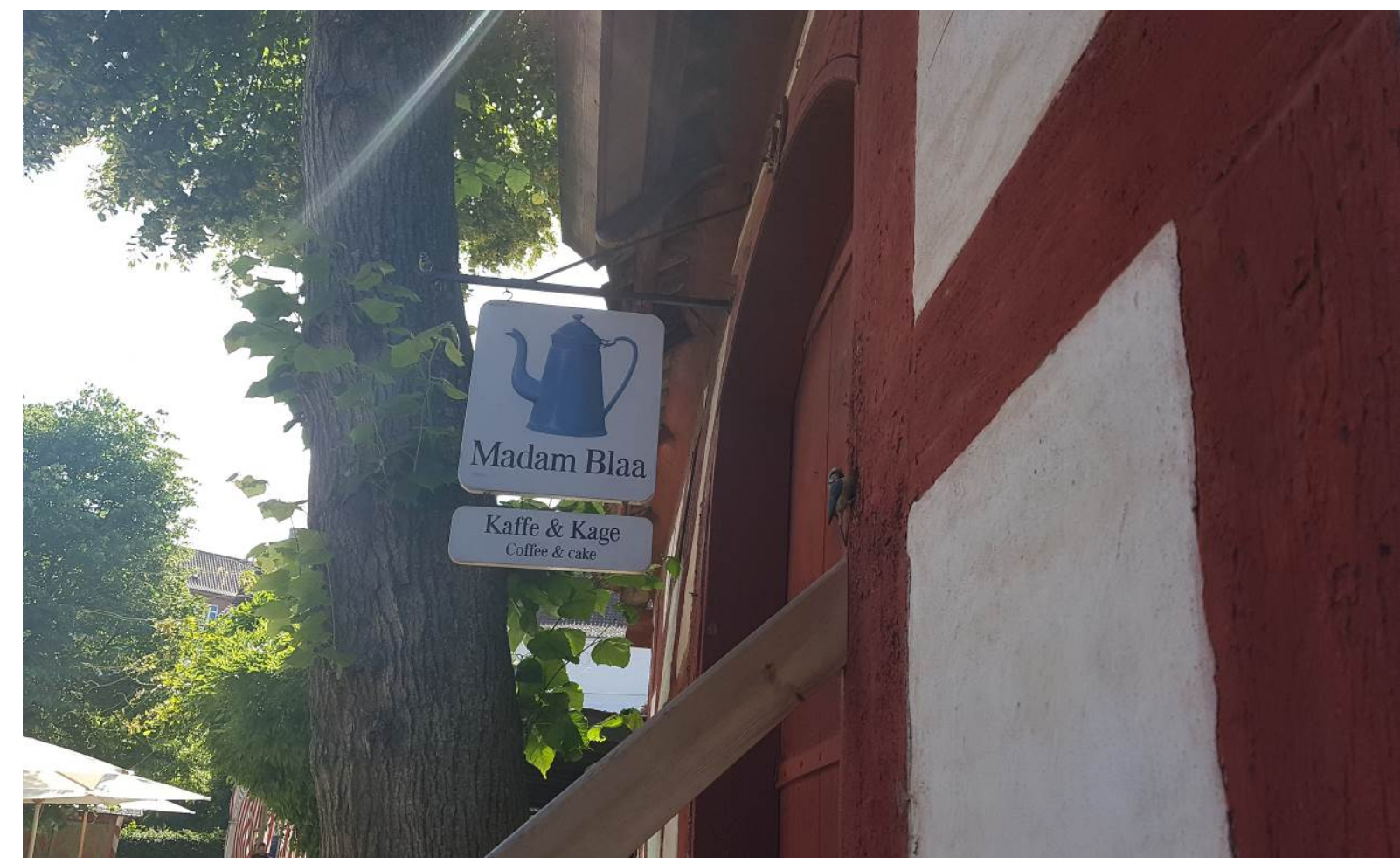

Figure 12: Café in an open-air museum in Aarhus, Denmark. The traditional house was most likely not meant to offer an extra dwelling layer for the family of titmice within its structure. However, as opposed to current tendencies, this structure offers opportunistic use and has developed into a cross-species co-living situation over time. (Photo: Davidová, 2018)

\section{Non-anthropocentric eco-systemic service design}

Landscape, if it is to be inhabited, needs to provide synergised non-anthropocentric ecosystemic services. This fact is often neglected in human-oriented cultural landscapes that tend to put its species on top of its hierarchy. The key realisation is that we do not need to invent sustainable human communities from scratch, as we can learn from the communities that have sustained themselves for centuries and from the models of nature's ecosystems, such as communities of plants, animals and microorganisms (Capra, 2005a, 2005b). An interesting example of how a synergy of diverse environmental agency and forces can serve a coperformance is a bioluminescent fly larvae in 'glow worm' caves that together with the river, air flow and the larvae's starry sky simulation; all co-performing and achieving an edible landscape with targeted climate comfort ${ }^{12}$ (see Figure 13). Such exploitative synergy could be involved with larger co-living systems and/or more. The example shows that diverse species require diverse non-anthropocentric eco-systemic services, which are often cross-referenced across a variety of species and biotic and abiotic agents. To sustain a biodiverse co-performing landscape, we need to sustain its rich and diverse provisions across the eco-systems and biosphere. This statement points back towards the field of architecture and urban and other cultural landscape design, as there is not much left of the 'non-cultural' landscape.

Zeithaml et al. describe Service design as "a form of architecture that involves processes rather than bricks and mortar" (Zeithaml, Parasuraman, \& Berry, 1990). Sevaldson points out that the traditionally fixed roles - the providers of objects (and services) to the ones that receive them (the users) - have been challenged by service design theory. There, the user is allegedly co-designing the service in the moment of consumption, and the notion of participation and co-design is inherent in user-oriented design methodology. However, the user in service design is normally perceived as congruent with the consumer of particular services. Therefore, he suggests a multi-centric approach to design with a non-anthropocentric 
perspective (Sevaldson, 2018). The processes can neither be performed nor purely received by humans and cannot be designed with a purely human orientation. In the shift towards the postanthropocene, cities and other humanised landscapes must cover human-oriented eco-systemic services and, therefore, also processes (which tend to be synonymous here). These services and processes should also not be purely provided by humans, i.e. insects co-create the fast food restaurants (covered by insect hotels) for birds and bats. The shift from the anthropocene towards the post-anthropocene, however, cannot emerge without human involvement unless we consider a total humanitarian catastrophe. Therefore, we cannot reach environmental justice without social justice, and vice versa (Davidová \& Zímová, 2018; Haase, 2017; McIntyreMills, 2014).

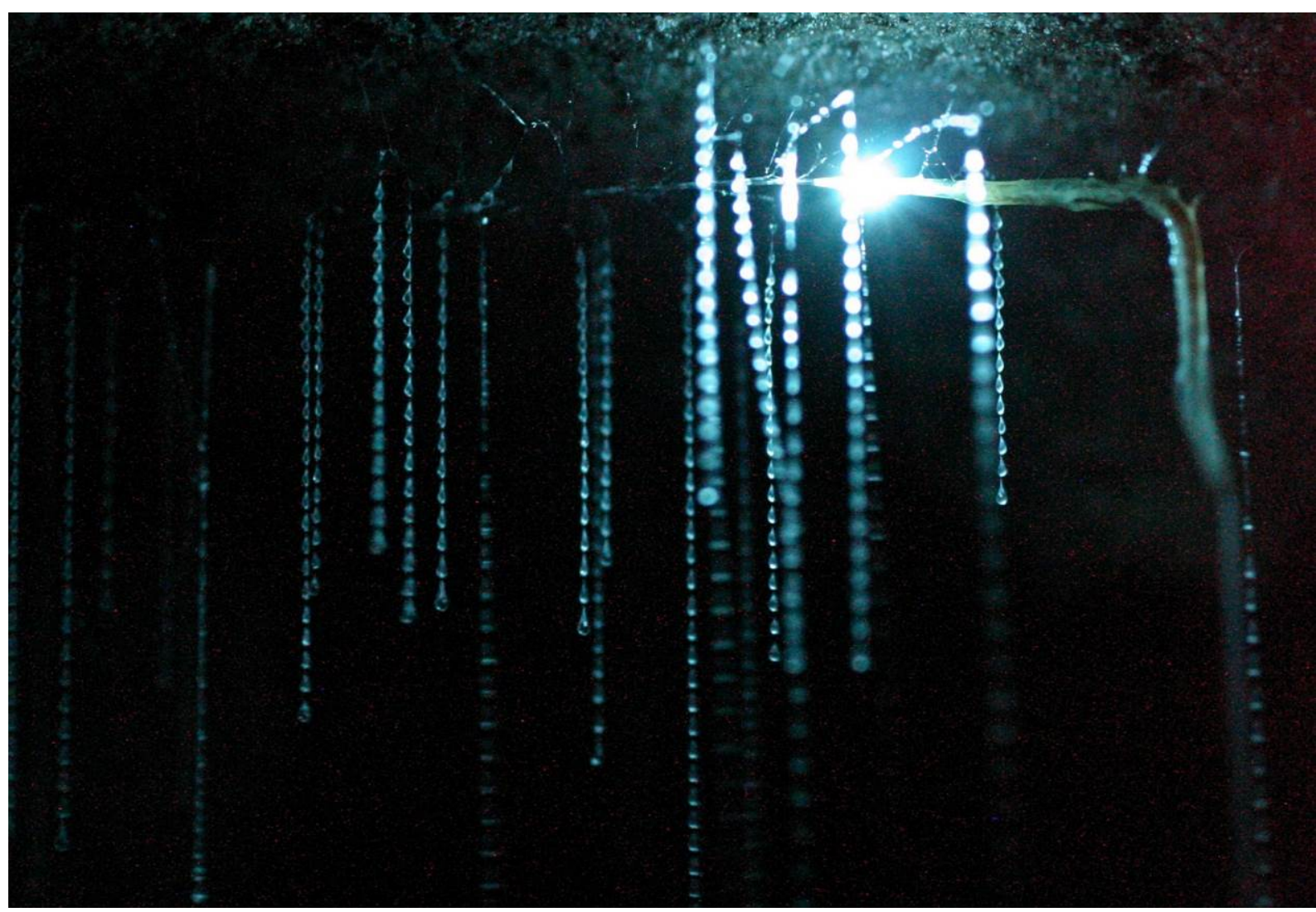

Figure 13: Waitomo Spellbound Caves - wires and bioluminescence of Diptera larvae (Photo: Chandler 2019, with the courtesy of Spellbound Caves).

The commonly used term of ecosystem services is, by definition, designed to bring benefits to those involved. However, in this notion, the involved ones are traditionally targeted as purely human (Pauleit, Zölch, Hansen, \& Randrup, 2017). In SAAP, by contrast, the modified term eco-systemic services is understood as non-anthropocentric. Saying this, it means that the 'ones involved' also cover non-human biotic and abiotic, living and non-living agents that are coperforming within the ecosystem and biosphere. Their benefits are distributed through the actions of a) culture and sociality, such as gigamapping and EnviroCity festivals (see i.e. Figure 3, Figure 4, Figure 5, Figure 6 and Figure 14); b) healthy nutrients, such as honey-producing species, seeds or hotels accommodating food (see, i.e. Figure 8, Figure 9, Figure 14 and Figure $15)$; c) healthy habitats, such as climate comfort and clean air (see, i.e. Figure 7, Figure 8, Figure 9 and Figure 12) and d) safe transition and exchange paths across the eco-system ${ }^{13}$ (see 
Figure 16) and a synergy of all the above mentioned services (see Figure 16). The beneficiaries and agency of course involve also humans, among other participants.

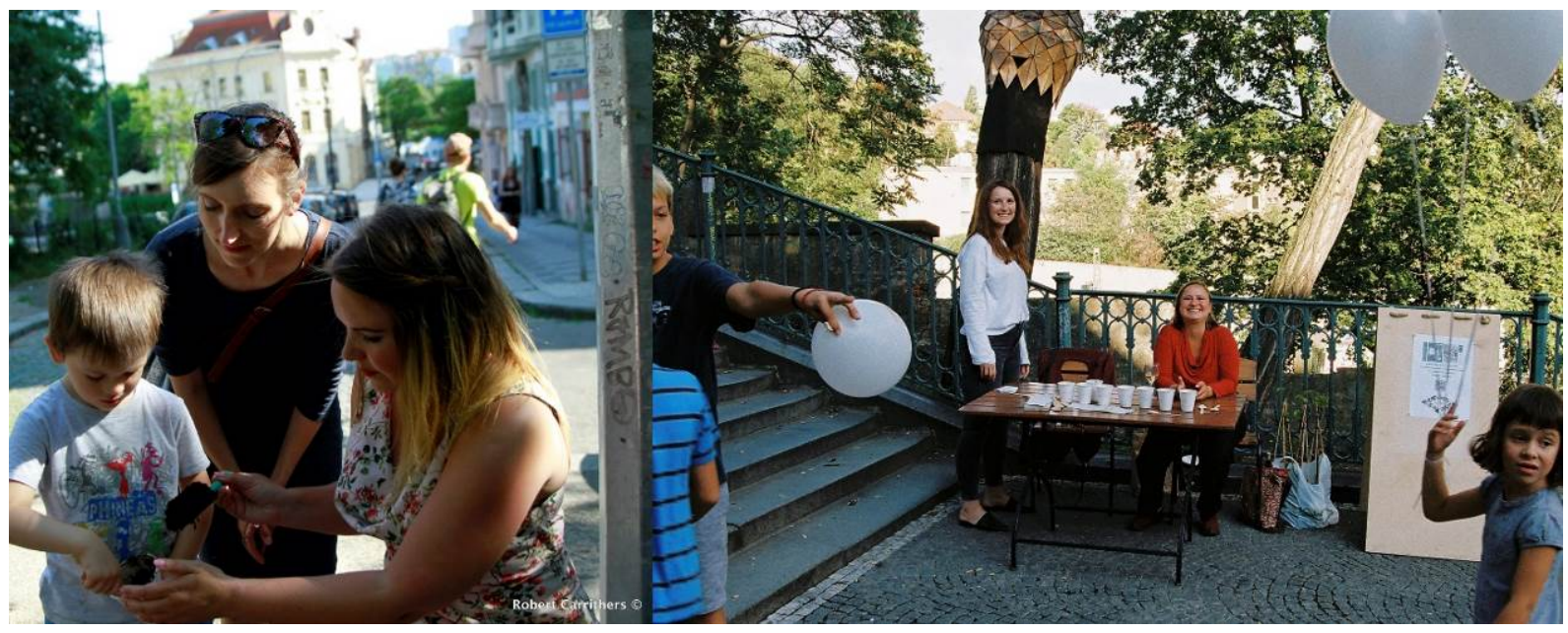

Figure 14: From left to right: a) Seed-Bombing at the EnviroCity 2017 Festival by Collaborative Collective and COOLand collaboration (Photo: Carrithers, 2017); b) Experience the City Other Way Festival 2018 - Collaborative Collective's stand with hands-on teaching services for DIY bird food production services for the coming autumn (Photo: Friends of Nusle Stairs, 2018).

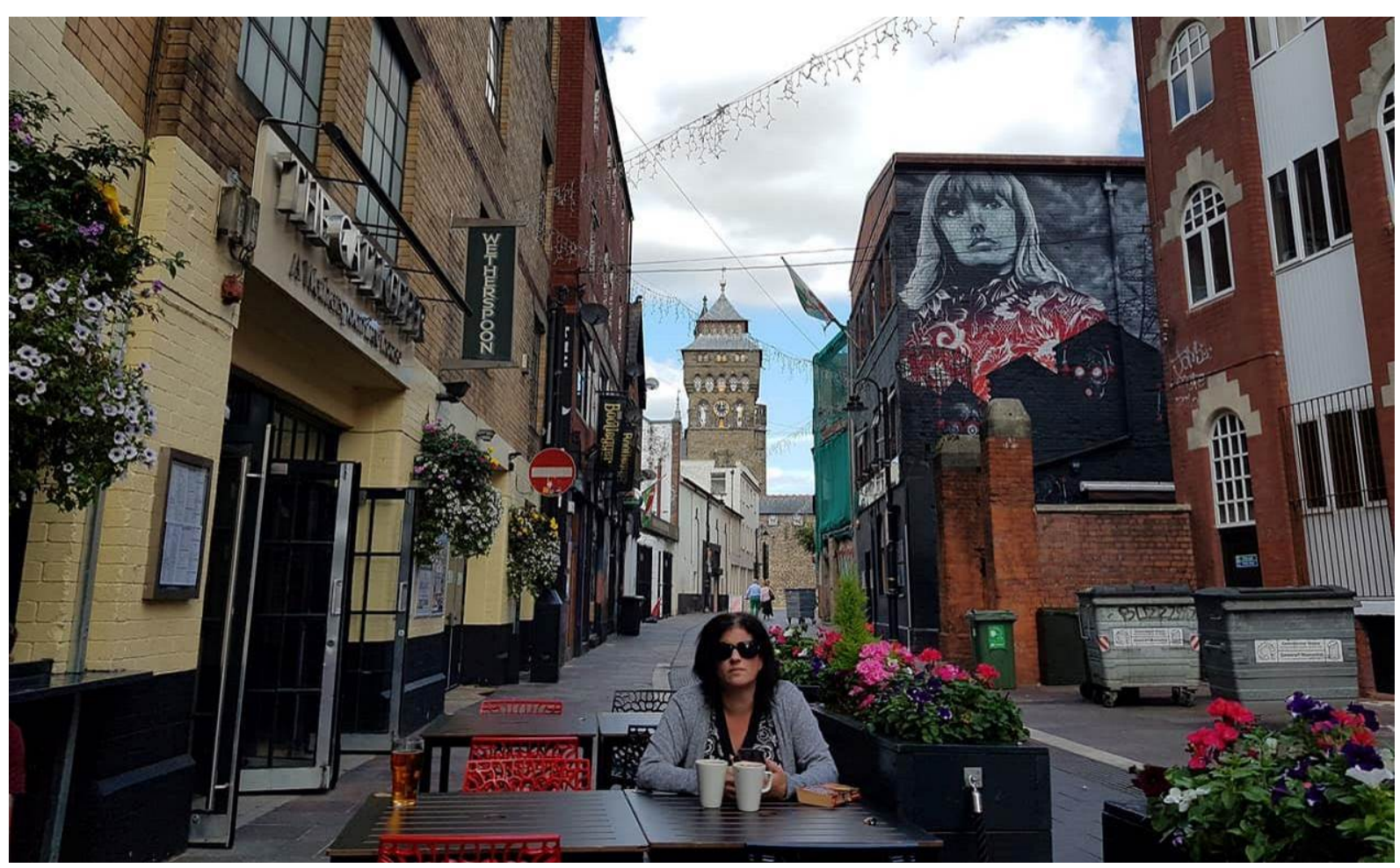

Figure 15: This restaurant in the city centre of Cardiff, Wales, serves as a refreshment station for both humans, bumblebees and butterflies, generating more feasible paths across the city (Photo: Davidová, 2018). 


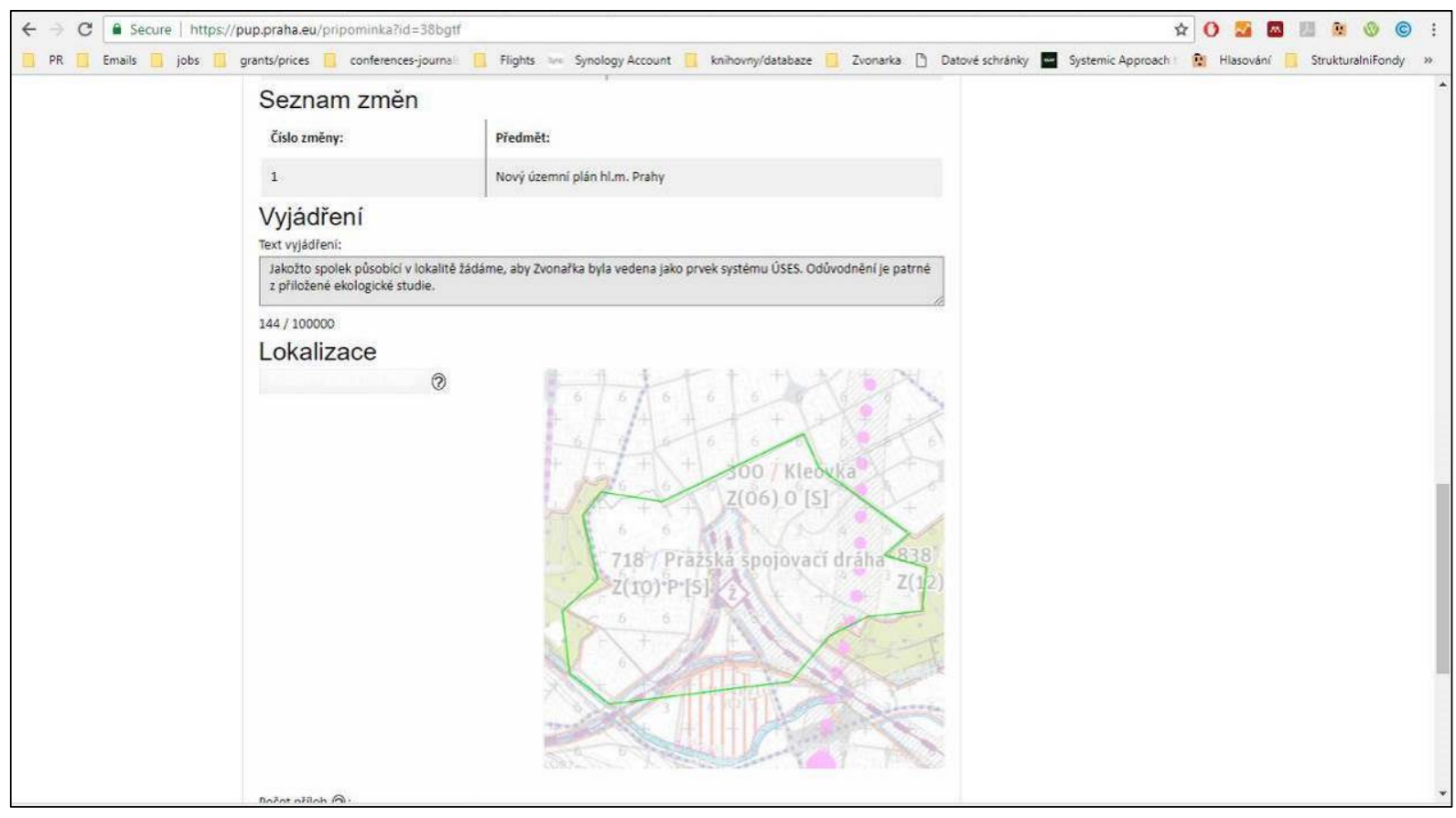

Figure 16: Questioning barriers in bio-corridor of too little planned land protection in the Metropolitan Plan proposal in the investigated location of COLridor I - remarks from the Collaborative Collective NGO to the Municipality of Prague (screenshot and marking: Davidová, 2018).

\section{Co-design, co-creation and DIY}

Sanders and Stappers point out that the next new thing in the changing landscape of design research has become co-designing with the users (Sanders \& Stappers, 2008). The traditional mindset of designing for [instead of with] people still operates in architecture and fashion design and even in the more open designers' notion of 'designing with', more stakeholders than just users need to be involved (Sanders \& Stappers, 2014). SAAP argues that the notion of users should be seen in a much more holistic way. The users or agents within the design process should be multiple, involving living and non-living, biotic and abiotic and human and non-human participation. This approach of a facilitator rather than an activist is stimulating generative service and adaptation co-creation instead of revolution. Interaction through the engagement of, and with others, and of and with the food chain can, for example, generate large time-based changes across the social, cultural, economic, political and ecological systems, as discussed by Govera and Evans (Govera \& Evans, 2018). Such changes are iterative and transferable on various scales by sharing technological tools (Baibarac \& Petrescu, 2019; Davidová, 2019b).

This interactive agency can be achieved across multiple stakeholders and disciplines in many ways, such as a) when planning (see Figure 3); b) within the production process, on the go in real time and real life (see, i.e. Figure 10, Figure 17 and Figure 18); or c) through noncommercial Creative Commons-licensed DIY iterations (Creative Commons, 2017) by communities under other local specific parameters (see Figure 9 and Figure 19). These multiple stakeholders and disciplines should cover the biotic and abiotic, living and non-living agents and agency communicated by those who cannot be represented, as explained by Sevaldson regarding gigamapping (Sevaldson, 2017). SAAP is multi-layering and cross-referencing these media and agency layers. These multi-agency co-creative and co-design processes generate the integral design's co-performance that, in traditional terminology, would be called the design result. However, this design result is not stable. This 'result' is in the process of real time and real life co-performative participation ${ }^{14}$. 


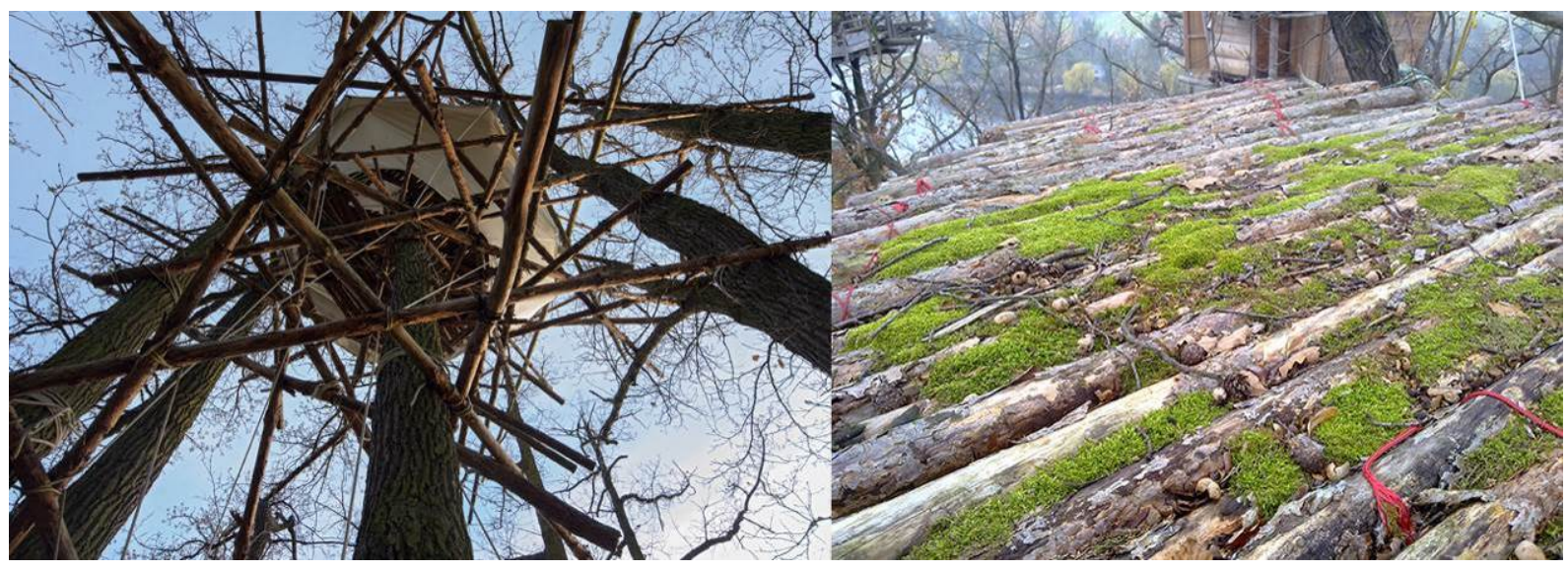

Figure 17: SpiralTreeHouse cultural landscape prototypical intervention (Photos: Zapletal 2014; Davidová, 2012).

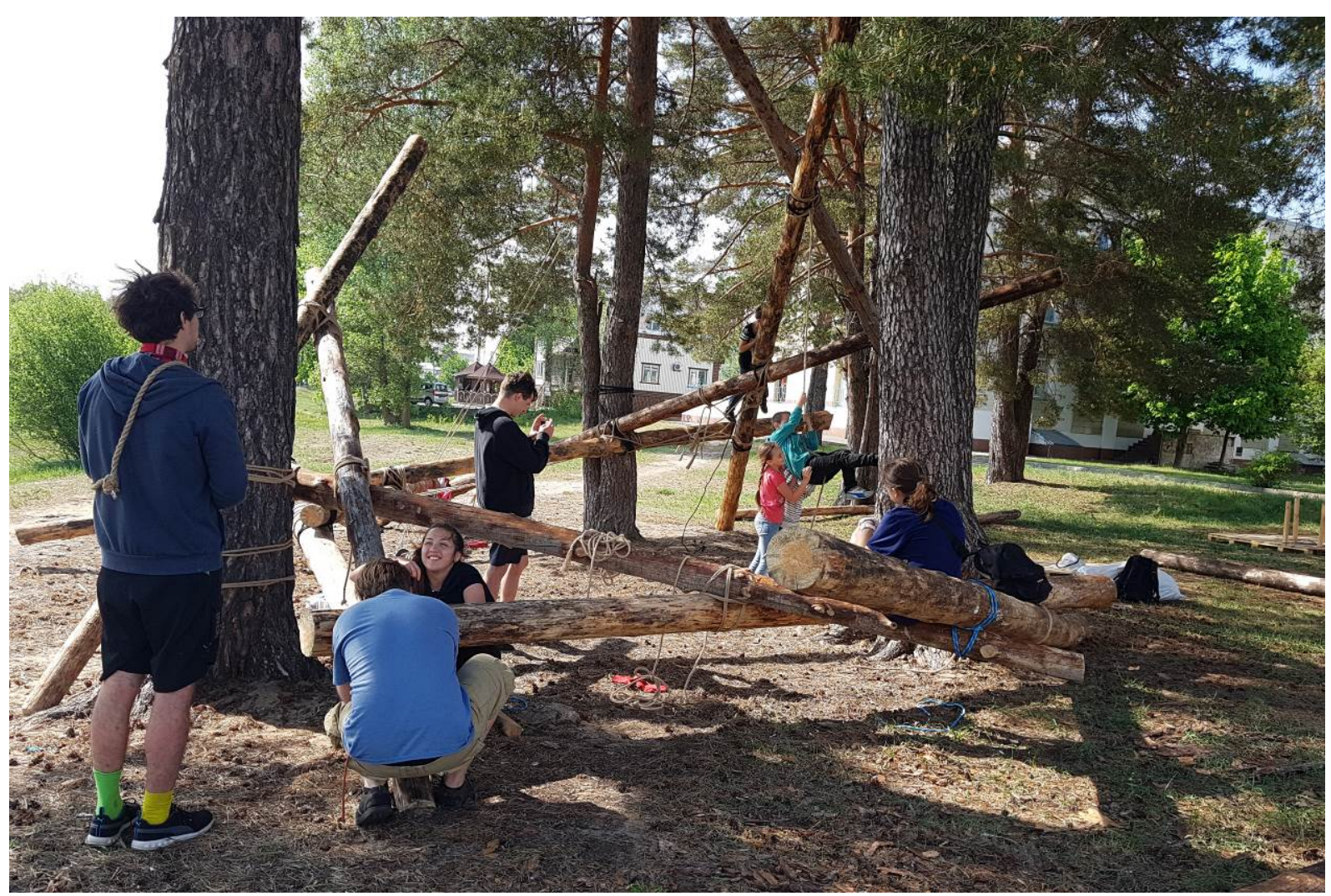

Figure 18: The construction site of the Co-oCo-oNest prototypical semi-urban intervention (Photo: Davidová, 2018). 


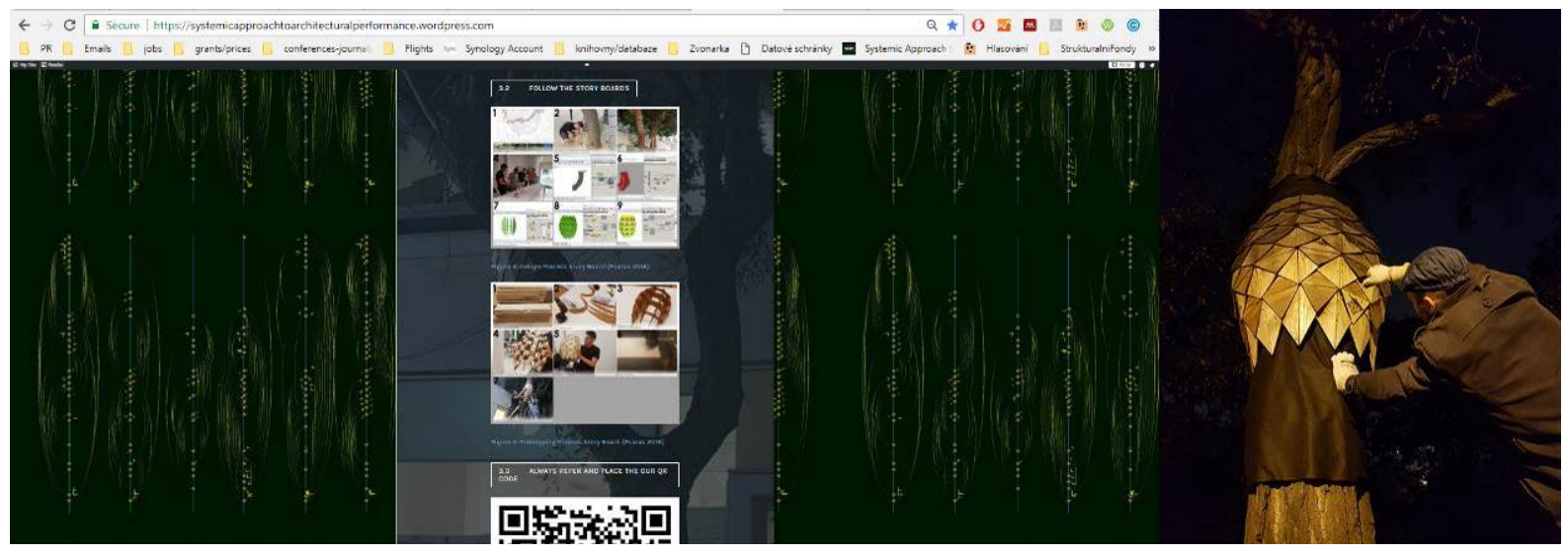

Figure 19: DIY recipe with downloadable parametric code of TreeHugger CY on the SAAP blog and updating the Prague TreeHugger CZ prototype with a QR code that leads to the site (Photo: Davidová, 2018).

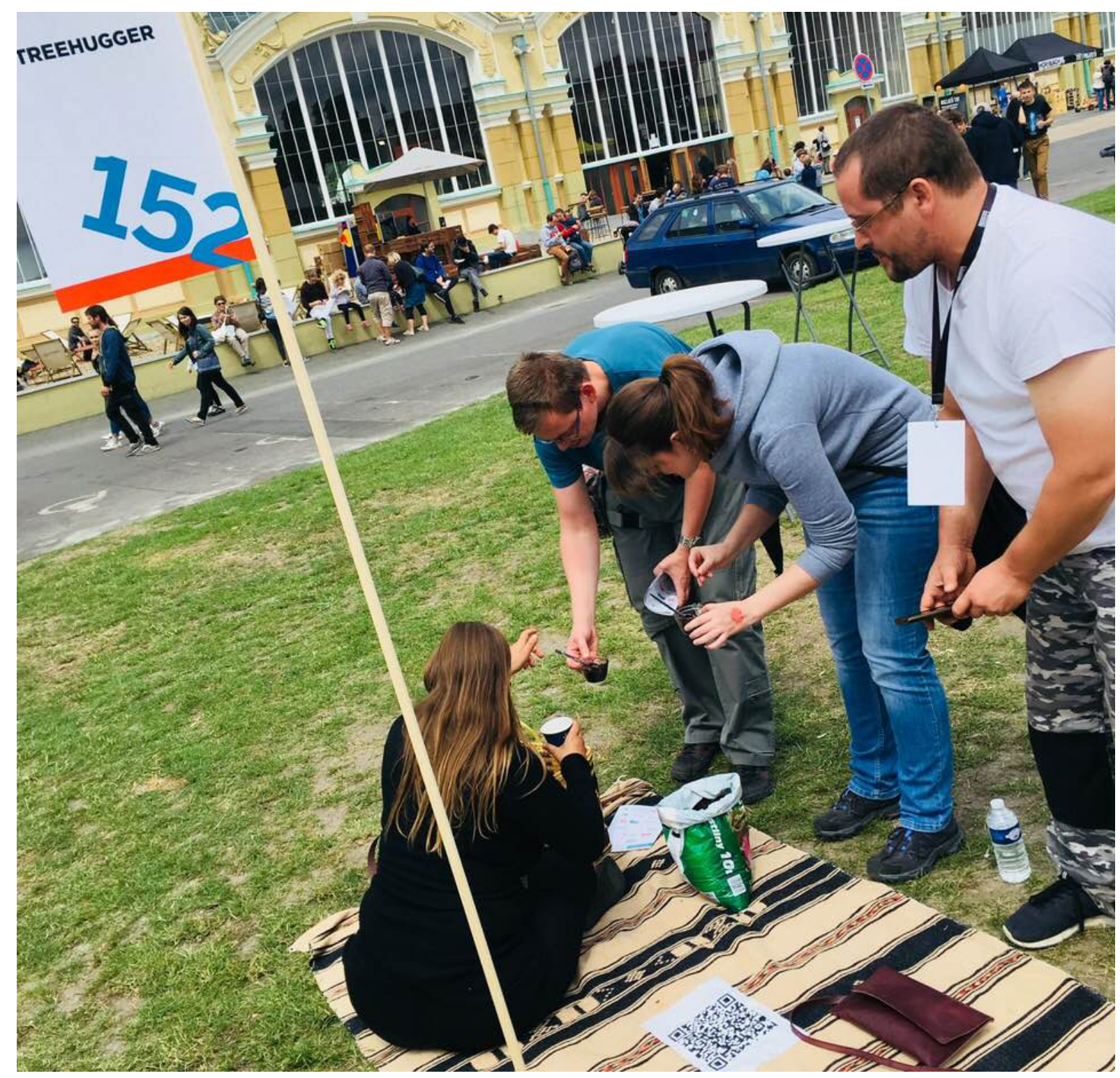

Figure 20: Non-anthropocentric refreshments at Maker Faire, Prague, 2018 (Photo: Horák Goryczka, 2018). 


\section{Synthesis}

The studies (see Figure 21) within SAAP aim to co-generate the concept of 'ecological urbanism' through 'anticipation, sensing, curation, collaboration, production, interaction, mobilisation, measures, adaptation and incubation' as suggested by Mostafavi and Doherty (2016). The research focuses on non-anthropocentric eco-systemic service design through coperformative, eco-systemic 'prototypical urban interventions' (Doherty, 2005). Such approaches gain from collective trans-disciplinary and trans-agency knowledge and actions gathered through multiple stakeholders.

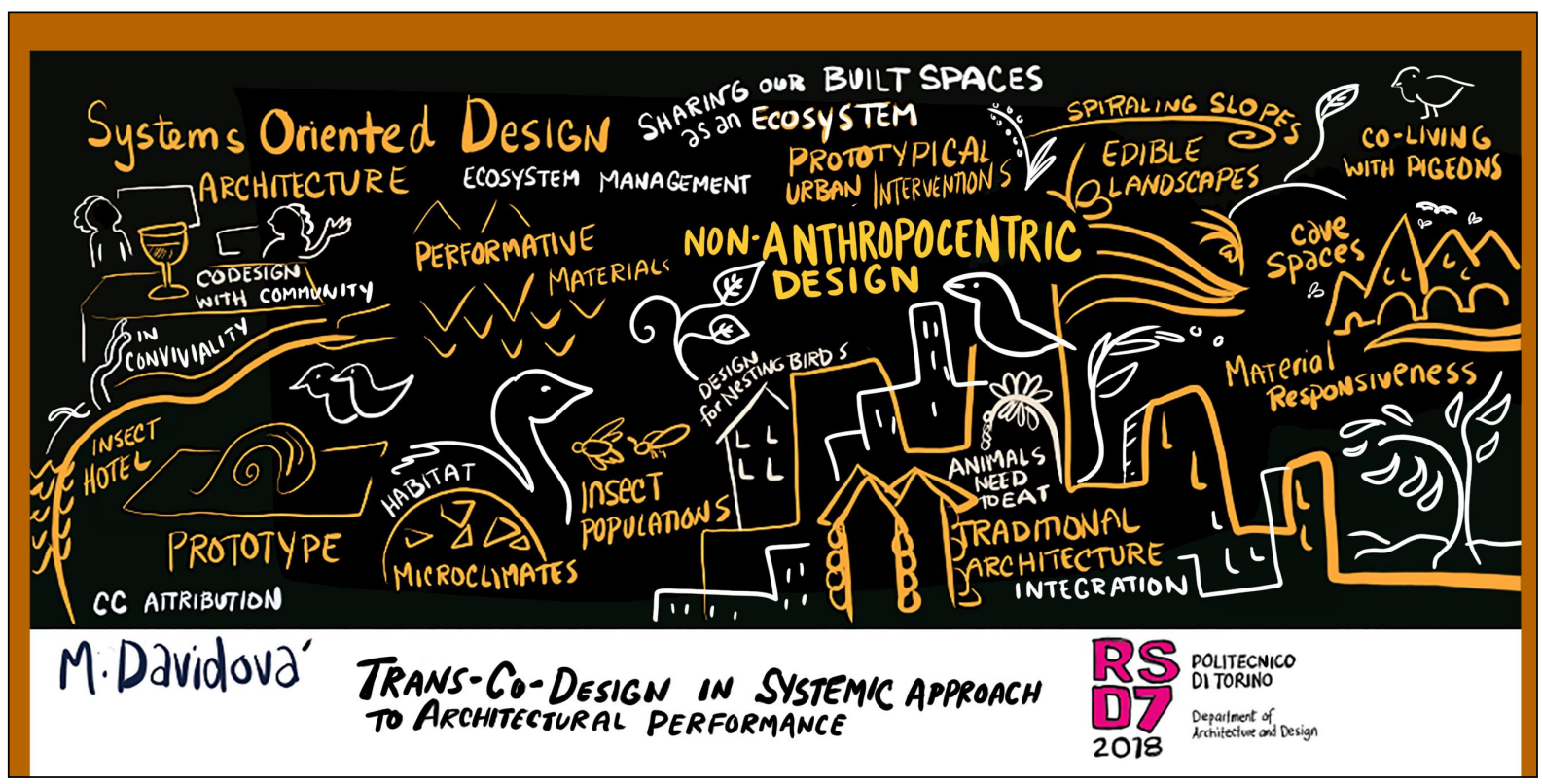

Figure 21: Sketchnotes from the paper presentation at the RSD 7 conference (Kambitsch, 2018).

One of the key interventions is the responsive wood insect hotel, TreeHugger (see Figure 22), for example. It is parasiting on a tree trunk in the middle of a central urban eco-top. TreeHugger is a small object. However, such intervention applies detailed climate moderation solutions through responsive wood inhabited and co-performed by the algae for a variety of insect species' needs to create their liveable and/or preferred environment. These, in reference to the larger eco-systemic network, are to generate an 'edible landscape' (Creasy, 2004) for, e.g. bats and birds, while another fast food of blooming plants and seed bombs are generated to feed these insects. All this is integrated through, e.g. the multi-genre festival EnviroCity representing the synergy of natural, social and cultural environment with its generative agendas of recipes for DIY and extension of exhibited gigamaps. Such initial projects on sustainable architectural speculations are transforming into sustainable speculations for eco-systems, covering and crossing multi-species and multi-non-living forces, multi-cultural, multi-political and multi-social and multi-biotechnological environment agendas. They are not only intervening through habitation but also through a sustainable eco-system of co-living with nutrients, genetic and other material resources, societies, cultures and collaborative political agendas: the environment of 'flourishing for all' (Ehrenfeld \& Hoffman, 2013).

The gigamapping of such prototypes, with diverse material and time frames or constraints focuses on detailed human and non-human, living and non-living environmental interaction. This gigamapping studies, in SAAP, involves and cross-refers the penetrable layering of architectural and urban design applications and speculations and its speculative studies on related indigenous, traditional or natural existing cases. This is for the reason that 
such (indigenous) systems which celebrate life demonstrate (human) sharing with community extension to our relatives on the land - the plants, fish, birds, and animals who share their lives with ours (Armstrong, 2005). The indigenous, traditional or natural architectures are in this research by co-design, seen as greatly ever-evolving prototypes that were or are tested, and thus co- and re-designed over generations, based on the synergy of natural, social, political, technological and other changes as their driving force ${ }^{15}$ (see Figure 23, Figure 24 and Figure 25).

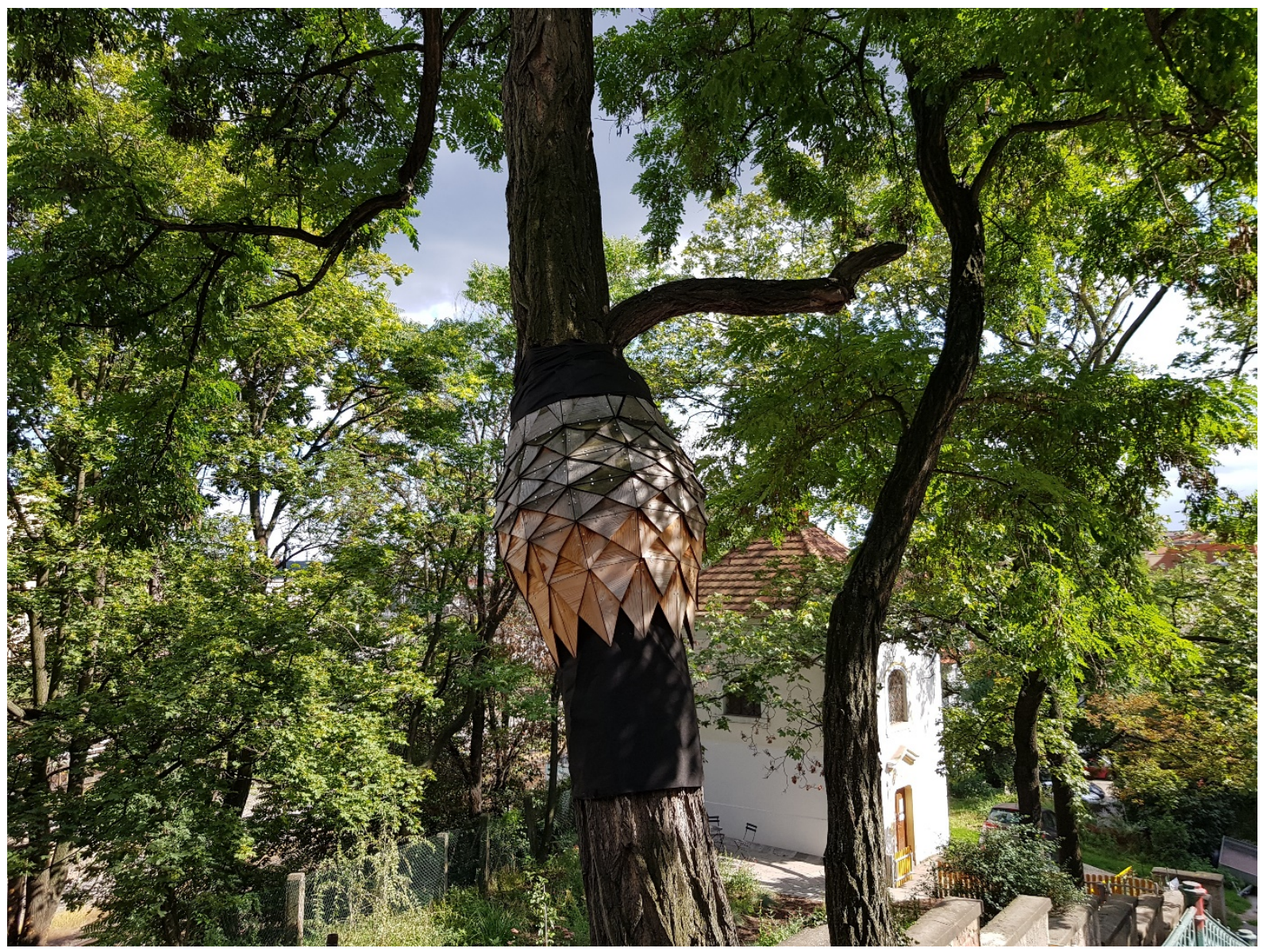

Figure 22: The TreeHugger $C Z$ responsive insect hotel prototype after its biotic and abiotic interaction over 1.5 years. The prototype applies Ray 2 panelling (see Figure 6) adjusted to double-curved surfaces (Ray 4) (Davidová \& Prokop, 2018) and is a result of trans-disciplinary co-design - the transco-design (Photo: Davidová, 2019). 


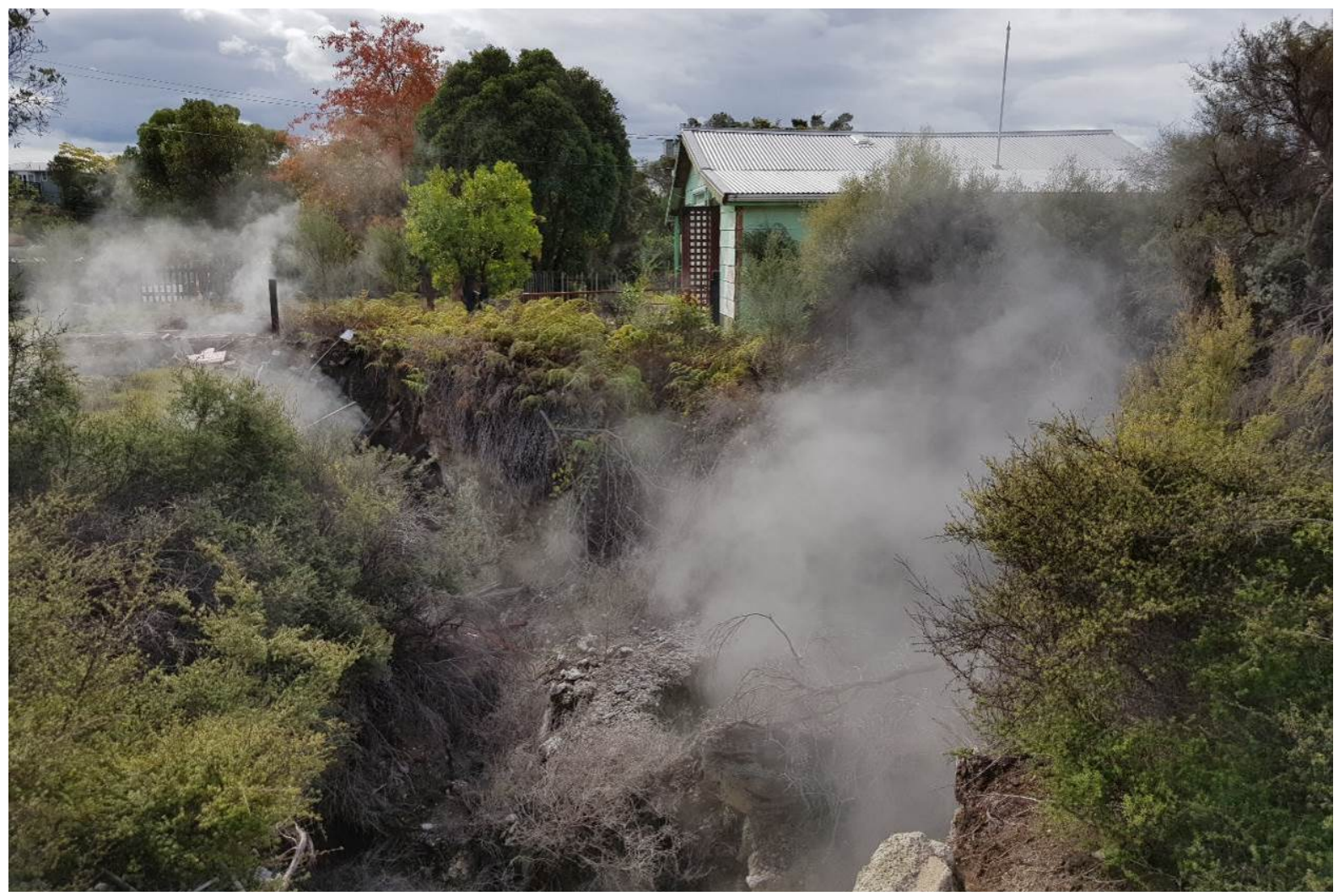

Figure 23: Whakarewarewa Living Maori Village changing landscape in the continuous energy exchange of natural forces, providing health as well as destruction (Photo: Davidová, 2019).

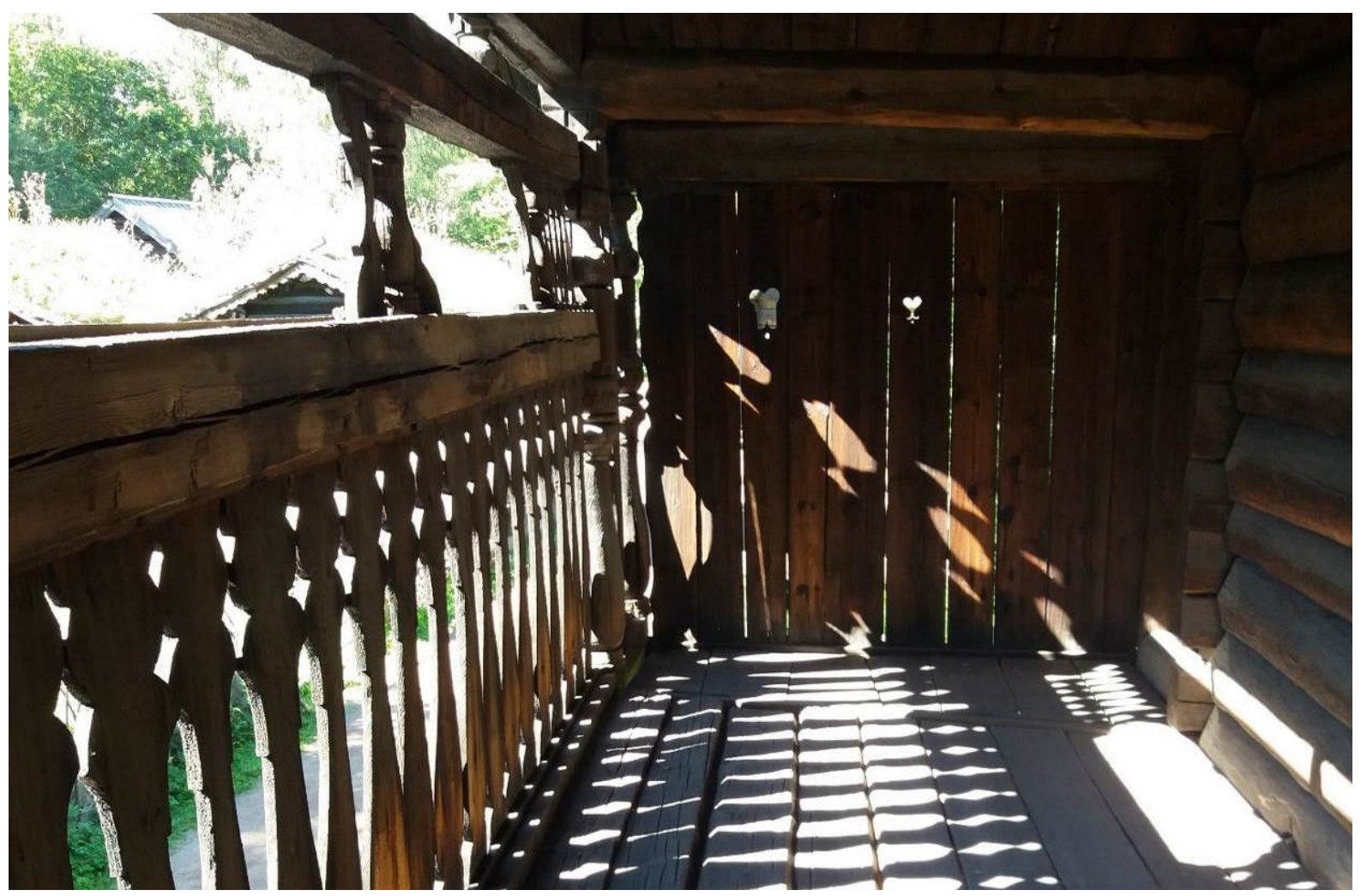

Figure 24: Svalgang of almost a hundred years of alder. Loft storehouse structure from Nes, Hallingdal, from 1700-1797. Photographed at the Oslo open air museum (Photo: Raková, 2017). 


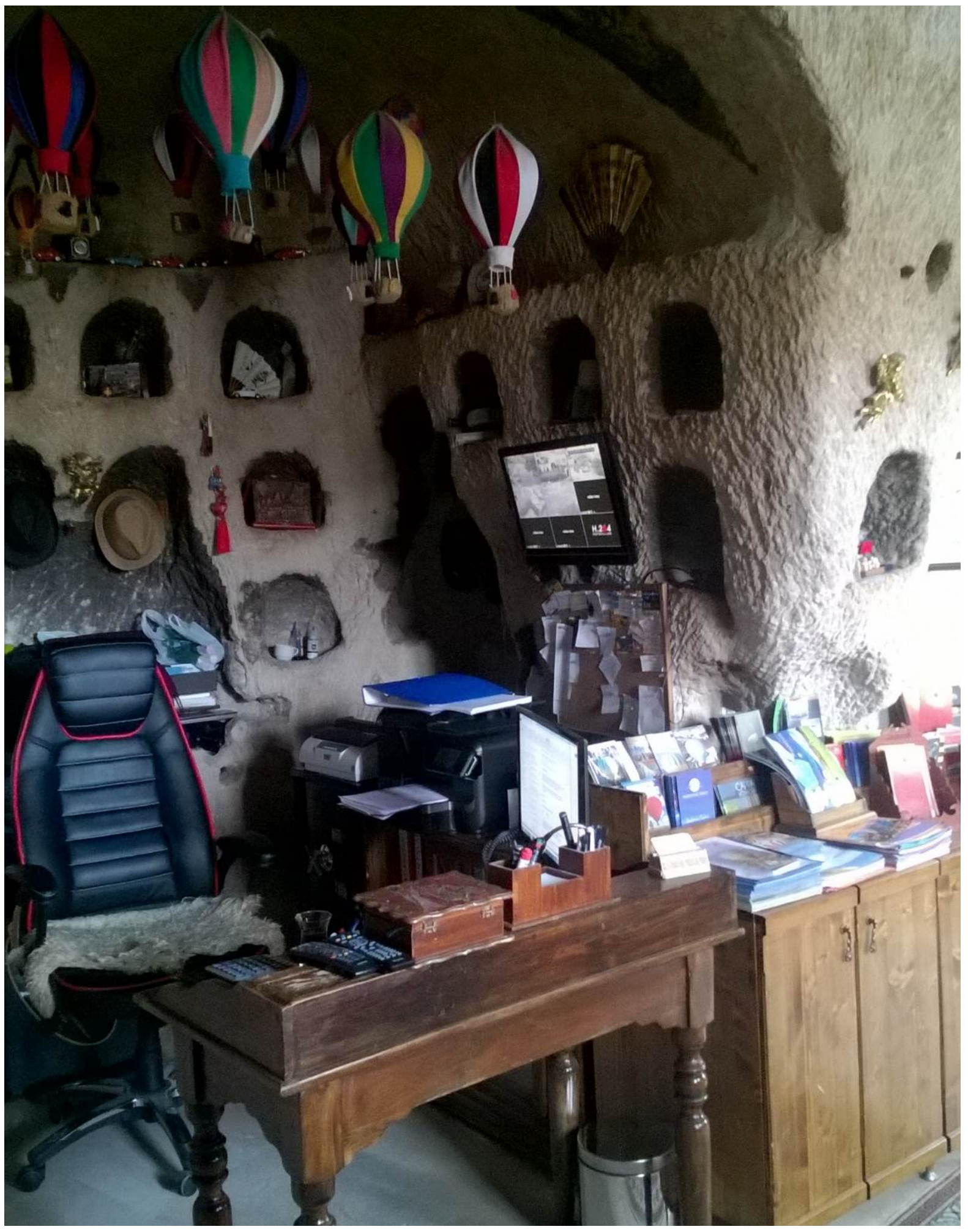

Figure 25: Former pigeon house that was rebuilt into a dwelling, today serving as the hotel reception area. City of Göreme (Photo: Davidová, 2016).

In reference to such socio-environmental processes of indigenous, traditional and natural architectural and urban design existing prototypes, the real life co-design laboratory follows similar feedback loops in its research by co-design. From the development of the first and very early research stage, the prototype is followed by gigamapping its environmental interactions' speculations. These speculations are supported by sampling. The prototyping research takes 
several feedback paths that are, however, interconnected with the other subprojects. The processes of subprojects involve the following:

a) long-term first prototype observations when exposed to environmental settings;

b) observations of related natural, indigenous and traditional architectures;

c) various local specific fast iterations;

d) the new prototypes development based on condemned weaknesses of the prototype;

e) observations of related natural, indigenous and traditional architectures and both or more of the prototypes for planned practice application; and

f) various local specific fast iterations to investigate other potentials.

Through these prototypical long-term observations, the development of climate-material interaction and the related biotic agency takes place in time while it is co-designed by it [the agency in time] (see Figure 10 and Figure 22). At the same time, new prototypes are trying to answer observed weaknesses or adapt to different environment contexts where cases are built and observed again (see Figure 8). These answering are occurring within the same time, confronted with related indigenous, historical and natural reference studies with possible applications (see Figure 12, Figure 23, Figure 24 and Figure 25). Such studies aim to suggest and identify informed new methodologies and principles, so called 'schools of thought' for practice applications. The iteration paths test different local specific applications, and variations for rich research by co-design led education, governance, the not-for-profit sector and for-profit practice through public engagement as well as through DIY. This bottom-up approach of prototyping is followed by top-down applications, and speculations on natural, indigenous and traditional architectural references from extreme environment observations.

\section{Discussion}

The discussion illustrated through projects focuses on trans-disciplinary multi- and crosslayered, analogue and digital collaborative co-design processes. These are grounded in gigamapping for the generation of co-performance prototypes (see Figure 21). Therefore, they are not trying to resolve any 'tame problem' (Rittel \& Webber, 1973) but the 'wicked' (Rittel $\&$ Webber, 1973) processes. The processes attempt to do so through continuous generative dialogue across of the open boundaries of the real time investigated problematique (the complex open fields of problems). These prototypes and their processes are 'hyperobjective' and 'hyperobjects' (Morton, 2013). They are in its kind a way of 'reflective conversations' (Schön, 1983) in terms of large eco-systemic co-design. It is for this reason that methods such as trial and error or comparative analysis are inapplicable because one cannot rely on precedent or personal preference as well as it is not being clear which problem is to be addressed (Sweeting, 2018). Therefore, the prototypes are placed within public, social and natural environmental complexity for their generative co-interaction. This co-interaction is engaging co-living and co-creation across the particular urban and/or cultural landscape's eco-system and the interpretation of such through multi-genre performers and/or agents. While doing so, the real time performance and its reflection for future project stages are co-re-designed.

While the gigamap serves as a holistic generative and reflective discussion board, the prototypes serve for environmental material embodied tacit interaction, experience, observation and generation of new alterations ${ }^{16}$. Due to such layered, mixed and crossed processes, SAAP follows a 'walk in, walk out' approach (Wheatley \& Frieze, 2011), which the author interprets as a third order cybernetics approach when the [co]designer oscillates between being inside and outside of the system (Davidová, 2019b). This oscillation occurs in reference to the design constraints (Fischer \& Richards, 2017). Similar learning processes have been expressed by Silveira, the fifth grader from the Kaitlin St. James: 
When you are inside, and you're learning about the plants [meaning indoor class - outside of the (eco)system] you say, 'Oh, this is this kind of plant'. But if you are outside [meaning exterior - inside of the (eco)system], you can feel it, see it, and observe it; you understand more. When I am outside, I can see all the beautiful scenes, and when you turn those scenes to education, that actually works for me. You use your scenes to use and detect life.' (Barlow, Marcellino, \& Stone, 2005, pp. 153).

The above quotation was said in the meaning of the interior and exterior of the classroom when the interior expresses indirect external knowledge and learning, and the exterior internal knowledge and learning differentiated through architectural material boundaries. This symmetry of the system constraints of knowledge, learning and further on designing and the material system constraints does, however, have no sharp but penetrable boundaries that are also cross- and multi-layered, and are referenced in different co-performing eco-systems of architectural and urban designs; and further on within the biosphere and more.

A similar oscillation between inside and outside with full-scale prototyping in reference to co-design processes (in this case, trial and error) was discussed by Capjon (Capjon, 2005). However, in SAAP, these processes are perceived as generative time-based 'results', codesigned and co-performed with the overall eco-system in time. The above also implies that the field calls for broadening the approach of Cities for People (Gehl, 2010) towards the wide participation of both biotic and abiotic, living and non-living agency within one coperformative eco-system, that is, the real-life co-design laboratory (Davidová et al., 2018).

\section{Conclusions}

In this paper I tried to demonstrate the necessity of a need to mix, cross-relate and integrate the living and non-living, human and non-human, analogue and digital processes based on the involved agency and its position in time. These are cross- and multi-layered and scaled in order to target the eco-systemic synergy of the coming age of the post-anthropocene. This synergy can be mainly achieved through hands-on reflective research by co-design. SAAP is investigated through gigamapping and the eco-systemic prototypical urban interventions (Davidová \& Prokop, 2018), their related natural, indigenous and traditional prototypes' by time informed studies and their DIY iterations in real life and time - within the real life codesign laboratory. This situation occurs for the reason that designers can never design the overall system. Such a laboratory is not to be engineered (Davidová, 2017c) or controlled (Meadows, 2002), but co-designed through multiple dialogical generative feedback loops across the 'natural' and the 'artificial' eco-system, biosphere, or more.

Within the field of SAAP, the design management, methodology and collaborative design processes, the designs' results and their collaborative co-generative co-performances are fused into one collective collaborative process of time-based eco-systemic trans-co-design occurring in real time. This research, by co-design, reformulates the notion of the Nature in Design (Joachim, 2016) into a 'living nature co-design'. This reformulation also involves the co-design of 'artificial nature. That is to practice and to generate practice and DIY iterations for cities' and other cultural landscapes' biodiversity support and climate change adaptation, securing micro-climates, habitats and nutrients for many species, including humans. This is particularly important in a time when the awakening young generations are urging action for their survival and several countries, cities, institutions, associations and movements, starting with the UK and, followed by others, have declared a climate emergency while finally admitting that we are facing the $6^{\text {th }}$ biodiversity mass extinction caused by the Anthropocene. 


\section{Acknowledgements}

The following article is an extended conference paper: Trans-CoDesign in SAAP: The Multi-Layered Media and Agency in Creative Design and Its Processes' presented at the Relating Systems Thinking and Design 7, Models and Processes of Systemic Design session at the Politecnico di Torino in October 2018 (Barbero, 2018), organised by the Systemic Design Association a day prior to the conference (Systemic Design, 2018).

The discussed projects were developed and built within the framework of the Collaborative Collective, its collaborators and local communities:

Spiral TreeHouse (Cholín's adjacent forests, Czechia 2010) Authors: Marie Davidová, Prokop Závada

Building Team: Prokop Závada, Marie Davidová, Barbora Peterková, Anežka Závadová, Filip Dioszegi, Michal Vedral, Jan Hradilek

\section{Co-oCo-oNest - 86' Festival's Workshop (Slavutych, Ukraine 2018)} Workshop Tutors: Marie Davidová, Šimon Prokop

Workshop Participants: Nataliia Neshevets, Oleksandr Rezen, Olivia Dimitrishina, Andrii Zabolotnyi, Slavutych local community

COLridor II - installation for Czech National Heritage Institute Exhibition (Trébíč, Czechia 2018)

Design and Realisation Lead: Marie Davidová, Kateřina Zímová, Ondřej Michálek, Jan Zatloukal, Kateřina Gazdová, Arif Gönulf, Jan David

Building Team: Michal Stasiak, Tereza Čapková, Roman Čapka, Matěj Nejedlý, Vojtěch Viceník, Kamil Belán, Tomáš Novotný, Vladislav Větrovec, Tomáš Veselý, Ondřej Herzán

Client - Exhibition Theme and Concept: Kateřina Horák Goryczka

TreeHugger CZ and COLridor I project (Prague, Czechia 2017)

Authors: Marie Davidová, Šimon Prokop, Kateřina Zímová, Ondřej Michálek, Kateřina Horák Goryczka, Krištof Hanzlík, Kamil Trgala, Eliška Oberhofnerová, the Local Biotic and Abiotic Community of Prague 2 District (Co-Design)

\section{TreeHugger CY - eCAADe RIS 6 at the University of Cyprus} workshop (Nicosia, Cyprus 2018)

Workshop Tutors: Marie Davidová, Šimon Prokop

6th eCAADe RIS Organisation: Odysseas Kontovourkis

Site Analysis for Tree Pre-Selection and Permission Negotiation: Panagiota Konatzii, Michalis Psaras Prototyping Worksop Participants: Panagiota Konatzii, Michalis Psaras, Stefanos Kyprianou, Marko Vucic, the Local Biotic and Abiotic Community of Nicosia Centre (CoDesign)

\section{Marie Davidová}

Lecturer / Chair, MArch, MNAL, ARB, Ph.D.

Cardiff University, Welsh School of Architecture / Collaborative Collective, UK davidovam@cardiff.ac.uk 


\section{References}

Allen, S. (2011). Practice vs. Project. In M. Mitášová (Ed.), Oxymorón a pleonasmus: Texty kritické a projektivni teorie / Oxymoron \& pleonasm: Texts on Critical and Projective Theory (1st ed., pp. 181195). Prague: Zlatý řez.

Allen, T. F. H., \& Roberts, D. W. (1993). Foreword. In R. E. Ulanowicz (Ed.), Ecology, the Ascendent Perspective (pp. xi-xiii). New York: Columbia University Press.

Armstrong, J. C. (2005). En'owkin: Decision-Making as if Sustainability Mattered. In M. K. Stone \& Z. Barlow (Eds.), Ecological literacy: educating our children for a sustainable world (1st ed., pp. 11-17). San Francisco: Sierra Club Books.

Baibarac, C., \& Petrescu, D. (2019). Co-design and urban resilience: visioning tools for commoning resilience practices. CoDesign, 15(2), 91-109. https://doi.org/10.1080/15710882.2017.1399145

Barbero, S. (2018). Relating Systems Thinking and Design 7: Challenging Complexity by Systemic Design thowards Sustainability (p. 602). Torino: Systemic Design Association. Retrieved from https://systemicdesign.net/rsd7/proceedings/conference/

Barlow, Z., Marcellino, S., \& Stone, M. K. (2005). Leadership and the Learning Community: An Interview with Jeanne Castella, principal of Mary E. Silveira School, San Rafael, California. In Z. Barlow \& M. K. Stone (Eds.), Ecological literacy: educating our children for a sustainable world (1st ed., pp. 149-260). San Francisco: Sierra Club Books.

Bateson, G. (1979). Mind and Nature: A Necessary Unity. New York: E.P. Dupton.

Beesley, P. (2019). Living Architecture Systems: Notes on Progress. In P. Beesley, S. Hasting, \& S. Bonnemaison (Eds.), Living Architecture Systems Group White Papers 2019 (pp. 1-8). Kitchener: Riverside Architectural Press. Retrieved from http://livingarchitecturesystems.com/publication/whitepapers-2019/

Berg, M., Bing, M., Vold Halvorsen, K. B., Mork, P., Mørch, M., Odden, M., ... Wohlen, S. (2011). Norsk Folke Museum - The Open Air Museum. (P. Mork, Ed.) (1st ed.). Oslo: Norsk Folkemuseum.

Bernert, P., Haaser, A., Kühl, L., \& Schaal, T. (2016). Towards a Real-world Laboratory: A Transdisciplinary Case Study from Lüneburg. GAIA - Ecological Perspectives for Science and Society, 25(4), 253-259. https://doi.org/10.14512/gaia.25.4.7

Boehnert, J. (2015). Ecological Literacy in Design Education - A Theoretical Introduction. FORMakademisk, 8(1), 1-11. https://doi.org/10.7577/formakademisk.1405

Bratton, B. H. (2019). Further Trace Effects of the Post-Anthropocene. Architectural Design, 89(1), 14-21. https://doi.org/10.1002/ad.2382

Braun, M. (1992). Picturing Time. Chicago: Chicago University Press.

Burchett, K. (2014). Anthropocentrism and nature: An attempt at reconciliation. Teoria, 34(2), 119-137. Retrieved from https://www.researchgate.net/publication/279113784_Anthropocentrism_and_Nature_An_Attempt_at_Re conciliation

Capjon, J. (2005). Engaged Collaborative Ideation supported through Material Catalysation. In Nordes 2005 - In the Making (pp. 1-6). Copenhagen: Royal Danish Academy of Fine Arts, School of Architecture. Retrieved from http://nordes.org/opj/index.php/n13/article/viewFile/231/214

Capra, F. (2005a). How Nature Sustains the Web of Life. In M. K. Stone \& Z. Barlow (Eds.), Ecological literacy: educating our children for a sustainable world (1st ed., pp. XIII-XV). San Francisco: Sierra Club Books.

Capra, F. (2005b). Speaking Nature's Language: Principles for Sustainability. In M. K. Stone \& Z. Barlow (Eds.), Ecological literacy: educating our children for a sustainable world (1st ed., pp. 18-29). San Francisco: Sierra Club Books.

Caviola, L., Everett, J. A. C., \& Faber, N. S. (2019). The moral standing of animals: Towards a psychology of speciesism. Journal of Personality and Social Psychology, 116(6), 1011-1029. https://doi.org/10.1037/pspp0000182

Checkland, P. (2000). Systems Thinking, Systems Practice. Chichester: John Wiley \& Sons LTD.

CHORA. (2017). CHORA - conscious city. Retrieved December 11, 2017, from http://chora.org/ 
Creasy, R. (2004). Edible Landscaping. Gainesville.

Creative Commons. (2017). Creative Commons - Attribution-NonCommercial 4.0 International - CC BY-NC 4.0. Retrieved December 9, 2017, from https://creativecommons.org/licenses/by-nc/4.0/

Cross, N. (1999). Design Research : A Disciplined Conversation. Design Issues, 15(2), 5-10. Retrieved from http://www.jstor.org/stable/1511837?origin=crossref

Czech Ornithologists Association. (2016). The Annual Report of the Czech Ornithologists Association / Výročni zpráva České společnosti ornitologické 2016 birdlife.cz. Prague. Retrieved from http://bigfiles.birdlife.cz/Vyrocni_zprava_CSO_2016.pdf

Davidová, M. (2016a). Ray 3: The Performative Envelope. In M. S. Uddin \& M. Sahin (Eds.), 2016 DCA European Conference: Inclusiveness in Design (pp. 519-525). Istanbul: Özyeğin University. Retrieved from https://www.researchgate.net/publication/307934969_Ray_3_The_Performative_Envelope

Davidová, M. (2016b). Socio-Environmental Relations of Non-Discrete Spaces and Architectures: Systemic Approach to Performative Wood. In P. Jones (Ed.), Relating Systems Thinking and Design 2016 Symposium Proceedings (pp. 1-17). Toronto: Systemic Design Research Network. Retrieved from https://www.researchgate.net/publication/312501181_Socio-Environmental_Relations_of_NonDiscrete_Spaces_and_Architectures_Systemic_Approach_to_Performative_Wood

Davidová, M. (2017a). Co-Habited, Co-Lived, Co-Designed and Co-Created Eco-Systemic Responsiveness in Systemic Approach to Architectural Performance: A Case Study on Interaction of Performative Solid Wood Envelope Ray and Algae. In M. João de Oliveira \& F. Crespo Osório (Eds.), KINE[SIS]TEM: From Nature to Architectural Matter (pp. 36-45). Lisbon: DINÂMIA'CET-IUL ISCTE - Instituto Universitário de Lisboa. Retrieved from https://www.researchgate.net/publication/317819704_Co-Habited_CoLived_Co-Designed_and_Co-Created_Eco-

Systemic_Responsiveness_in_Systemic_Approach_to_Architectural_Performance_A_Case_Study_on_Int eraction_of_Performative_Solid_Wood_Envelope_Ray_and_Alg

Davidová, M. (2017b). Systemic Approach to Architectural Performance: The Media Mix in the Creative Design Process. FormAkademisk - Research Journal of Design and Design Education, 10(1), 1-25. https://doi.org/10.7577/formakademisk.1713

Davidová, M. (2017c). Wood as a Primary Medium to Eco-Systemic Performance: A Case Study in Systemic Approach to Architectural Performance. Czech Technical University in Prague. https://doi.org/10.13140/RG.2.2.17123.45607

Davidová, M. (2018). Roles, Agency and Relations of GIGA-Maps in Systemic Approach to Architectural Performance: The Special Prototypes of Post-Anthropocene. In J. Bean, S. Dickinson, \& A. Ida (Eds.), AMPS Proceedings Series 12. Critical Practice in an Age of Complexity (pp. 114-132). Tucson: University of Arizona. Retrieved from http://architecturemps.com/wp-content/uploads/2018/11/AMPSProceedings-12-Critical-Practice-in-an-Age-of-Complexity.pdf

Davidová, M. (2019a). Designing Sustainability for All or Co-Designing Sustainability with All? In M. Ambrosio \& C. Vezzoli (Eds.), LeNS: Designing Sustainability for All! (pp. 558-563). Milan: LeNS - the Learning Network on Sustainabilty. Retrieved from http://www.lensconference3.org/images/program/VOLUME2.pdf

Davidová, M. (2019b). Intelligent Informed Landscapes: The Eco-Systemic Prototypical Interventions' Generative and Iterative Co-Designing Co-Performances, Agencies and Processes. In M. H. Haeusler, M. A. Schnabel, \& T. Fukuda (Eds.), Intelligent \& Informed - Proceedings of the 24th CAADRIA Conference (pp. 151-160). Wellington: Victoria University of Wellington. Retrieved from http://papers.cumincad.org/cgi-bin/works/paper/caadria2019_242

Davidová, M. (2019c). Systemic Approach to Architectural Performance. Retrieved December 4, 2019, from https://systemicapproachtoarchitecturalperformance.wordpress.com/

Davidová, M., Pánek, K., \& Pánková, M. (2018). Spiralling Slope as a Real Life Co-Design Laboratory. In J. Bean, S. Dickinson, \& A. Ida (Eds.), AMPS Proceedings Series 12. Critical Practice in an Age of Complexity (pp. 133-142). Tucson: University of Arizona. Retrieved from http://architecturemps.com/wpcontent/uploads/2018/11/AMPS-Proceedings-12-Critical-Practice-in-an-Age-of-Complexity.pdf

Davidová, M., \& Prokop, Š. (2018). TreeHugger: The Eco-Systemic Prototypical Urban Intervention. In O. Kontovourkis (Ed.), 6th eCAADe RIS 2018 Proceedings (pp. 75-85). Nicosia: University of Cyprus. Retrieved from http://papers.cumincad.org/cgi-bin/works/paper/ecaaderis2018_103

Davidová, M., \& Raková, D. (2018). Biodiversity and Climate Change Adaptation through Non-Discrete 
Architectural Spaces and Architectures: Systemic Approach to Traditions for Sustainable Futures. FormAkademisk - Research Journal of Design and Design Education, 11(4), Art. 4, 1-31. https://doi.org/https://doi.org/10.7577/formakademisk.2287

Davidová, M., \& Sevaldson, B. (2016a). 1:1, A Transdisciplinary Prototyping Studio. In J. Slyk \& L. Bazerra (Eds.), ASK.the.Conference 2016 (pp. 302-308). Warszaw: Warszaw University of Technology, Faculty of Architecture. Retrieved from https://www.researchgate.net/publication/307935449_11_A_Transdisciplinary_Prototyping_Studio

Davidová, M., \& Sevaldson, B. (2016b). NGO, Practice and University Driven Research By Design on Performative Wood. In M. S. Uddin \& M. Sahin (Eds.), 2016 DCA European Conference: Inclusiveness in Design (pp. 509-517). Istanbul: Özyeğin University. Retrieved from https://www.researchgate.net/publication/307934911_NGO_Practice_and_University_Driven_Research_ By_Design_on_Performative_Wood

Davidová, M., \& Uygan, E. (2017). Living in Bio-Climatic Layers: An Investigation of Cappadocian Caves in Relation to Today's Design and Its Futures. In F. Mahbub, S. Uddin, \& A. M. Khan (Eds.), International Design Conference: DESIGN EVOLUTION [Education and Practice] (pp. 1-12). Karachi: Indus Valley School of Art and Architecture. Retrieved from https://www.researchgate.net/publication/313759290_Living_in_Bio-

Climatic_Layers_An_Investigation_of_Cappadocian_Caves_in_Relation_to_Today\%27s_Design_and_Its Futures

Davidová, M., Zatloukal, J., \& Zímová, K. (2017). Responsive Transformer: The Bio-Robotic Adaptive Architecture. In F. Mahbub, S. Uddin, \& M. A. Khan (Eds.), International Design Conference: DESIGN EVOLUTION [Education and Practice] (pp. 1-8). Karachi: Indus Valley School of Art and Architecture. Retrieved from https:/www.researchgate.net/publication/313759423_Responsive_Transformer_The_BioRobotic_Adaptive_Architecture

Davidová, M., \& Zímová, K. (2017). COLridor: Co-Design and Co-Living for Sustainable Futures. In B. Sevaldson (Ed.), Relating Systems Thinking and Design 6: Environment, Economy, Democracy: Flourishing Together (pp. 1-20). Oslo: Systemic Design Research Network. Retrieved from https://systemic-design.net/rsd6/systemic-design-cases/\#davidova

Davidová, M., \& Zímová, K. (2018). COLridor: Co-Design and Co-Living Urban Adaptation. FormAkademiskResearch Journal of Design and Design Education, 11(4), 1-30. https://doi.org/https://doi.org/10.7577/formakademisk.2647

Doherty, G. (2005). Prototypes in Pinkenba. In Nordes 2005 - In the Making (Vol. 1, pp. 1-5). Copenhagen: Royal Danish Academy of Fine Arts, School of Architecture. Retrieved from http://www.nordes.org/opj/index.php/n13/article/view/262/245

Ehrenfeld, J., \& Hoffman, A. J. (2013). Flourishing : a frank conversation about sustainability (1st ed.). Stanford: Stanford University Press. Retrieved from https://www.researchgate.net/publication/274250501_Flourishing_A_Frank_Conversation_on_Sustainabil ity

Fathy, H. (1986). Natural Energy and Vernacular Architecture: Principles and Examples with Reference to Hot Arid Climates. Chicago and London: The University of Chicago Press. Chicago and London: The University of Chicago Press. Retrieved from http://archive.unu.edu/unupress/unupbooks/80a01e/80A01E00.htm

Fischer, T., \& Richards, L. D. (2017). From Goal-Oriented to Constraint-Oriented Design: The Cybernetic Intersection of Design Theory and Systems Theory. Leonardo, 50(1), 36-41. https://doi.org/10.1162/LEON

Gehl, J. (2010). Cities for People (Vol. 1). Washington, Covelo, London: Island Press. https://doi.org/10.1017/CBO9781107415324.004

Govera, C., \& Evans, J. (2018). Thinking Edibility Otherwise. Journal of Design and Science, (4). Retrieved from https://jods.mitpress.mit.edu/pub/issue4-evans-govera

Grooten, M., \& Almond, R. E. . (2018). Living Planet Report 2018: Aiming higher. Gland: WWF International. Retrieved from https:/www.wwf.org.uk/sites/default/files/2018-10/wwfintl_livingplanet_full.pdf

Haase, A. (2017). The Contribution of Nature-Based Solutions to Socially Inclusive Urban Development- Some Reflections from a Social-environmental Perspective (pp. 221-236). Springer, Cham. https://doi.org/10.1007/978-3-319-56091-5_13 
Hensel, M. (2010). Performance-oriented Architecture: Towards a Biological Paradigm for Architectural Design and the Built Environment. FORMakademisk, 3(1), 36-56. Retrieved from http://www.formakademisk.org/index.php/formakademisk/article/view/65

Hensel, M. (2012). Performance-oriented architecture: An integrated discourse and theoretical framework for architectural design and sustainability towards non-discrete and non-anthropocentric architectures. University of Reading. Retrieved from https://www.researchgate.net/publication/282856733_Performance-oriented_Architecture__An_integrated_discourse_and_theoretical_framework_for_architectural_design_and_sustainability_towa rds_non-discrete_and_non-anthropocentric_architectures

Hensel, M. (2013). Performance-Oriented Architecture: Rethinking Architectural Design and the Built Environment (1st ed.). West Sussex: John Willey \& Sons Ltd.

Hensel, M. (2019). The rights to ground: integrating human and non-human perspectives in an inclusive approach to sustainability. Sustainable Development, 1-7. https://doi.org/10.1002/sd.1883

Hensel, M., \& Menges, A. (2006). Morpho-Ecologies (1st ed.). London: AA Publications.

Hensel, M., \& Sunguroğlu Hensel, D. (2015). Architectural History from a Performance Perspective - The Latent Potential of Knowledge embedded in the Built Environment. In La Scuola di Pitagora (Ed.), Heritage and Technology: Mind, Knowledge, Experience - Le Vie dei Mercanti XIII International (pp. 794-802). Naples: La Scuola di Pitagora. https://doi.org/10.13140/RG.2.1.3409.7365

Irwin, T. (2015). Transition design: A proposal for a new area of design practice, study, and research. Design and Culture, 7(2), 229-246. https://doi.org/10.1080/17547075.2015.1051829

Jabi, W. M. (1998). The Role of Artifacts in Collaborative Design. In T. Sasada (Ed.), CAADRIA '98: Third Conference on Computer-aided Architectural Design Research in Asia (pp. 271-280). Osaka: Sasada Laboratory, Dept. of Environmental Engineering, Faculty of Engineering, Osaka University. Retrieved from http://papers.cumincad.org/cgi-bin/works/paper/203b

Joachim, M. (2015). A Century of Ecological Innovation. Architectural Design, 85(4), 68-73. https://doi.org/10.1002/ad.1928

Joachim, M. (2016). Ten archetypes of nature in design. Technoetic Arts, 14(1), 127-130. https://doi.org/10.1386/tear.14.1-2.127_1

Joachim, M. (2019). The Work of Terreform ONE. In P. Beesley, S. Hasting, \& S. Bonnemaison (Eds.), Living Architecture Systems Group White Papers 2019 (pp. 143-155). Kitchener: Riverside Architectural Pres. Retrieved from http://livingarchitecturesystems.com/publication/white-papers-2019/

Kempe, D. R. C. (1988). Living underground: a history of cave and cliff dwelling (1st ed.). London: Herbert Press.

Kera, D. (2018). Maker Faire Prague. Retrieved July 9, 2018, from http://prague.makerfaire.com/

Lagasse, P., \& Columbia University. (2016). The Columbia Encyclopedia (6th ed.). New York: Columbia University Press.

McIntyre-Mills, J. (2014). Systemic Ethics for Social and Environmental Justice. In J. McIntyre-Mills (Ed.), Systemic Ethics and Non-Anthropocentric Stewardship (pp. 121-153). Cham: Springer. https://doi.org/10.1007/978-3-319-07656-0_6

Meadows, D. (2002). Dancing with systems. Systems Thinker, 13, 2-6.

Morton, T. (2013). Poisoned Ground: Art and Philosophy in the Time of Hyperobjects. Symploke, 21(1-2), 3750. https://doi.org/10.1353/sym.2013.0025

Moxon, S., Moxon, J., \& Cougill, S. (2018). Team | Transforming London's Streets for Wildlife | Rewild My Street. Retrieved May 5, 2019, from https://www.rewildmystreet.org/team

Oxford University Press. (2004). World Encyclopedia (1st ed.). Published Online: Philip's. https://doi.org/10.1093/acref/9780199546091.001.0001

Pauleit, S., Zölch, T., Hansen, R., \& Randrup, T. B. (2017). Nature-Based Solutions and Climate Change - Four Shades of Green. In N. Kabisch, H. Korn, J. Stadler, \& A. Bonn (Eds.), Nature-Based Solutions to Climate Change Adaptation in Urban Areas (pp. 29-49). Cham: Springer. https://doi.org/10.1007/978-3319-56091-5

Pickering, A. (1993). The Mangle of Practice: Agency and Emergence in the Sociology of Science. American Journal of Sociology, 99(3), 559-589. https://doi.org/10.2307/2781283 
Plowman, C., Merritt, D., \& Fenton, J. (2013). Living Lights: The Glow Worms of Australia and New Zealand. Deviot: Cathie Plowman.

Rittel, H. W. J., \& Webber, M. M. (1973). Dilemmas in a General Theory of Planning. Policy Sciences, 4, 155169.

Sanders, E., \& Stappers, P. J. (2008). Co-creation and the new landscapes of design. CoDesign, 4(1), 5-18. https://doi.org/10.1080/15710880701875068

Sanders, E., \& Stappers, P. J. (2014). From designing to co-designing to collective dreaming: Three slices in time. Interactions, 21(6), 24-33. https://doi.org/10.1145/2670616

Scandinavian Green Infrastructure Association. (2019). Scandinavian Green Infrastructure Association. Retrieved May 6, 2019, from https://scandinavian-green-roof.org/

Schön, D. A. (1983). The Reflective Practitioner: How Professionals Think in Action. New York: Basic Books.

Sevaldson, B. (2004). Designing Time: A Laboratory for Time Based Design. In Future Ground (pp. 1-13). Melbourne: Monash University. Retrieved from http://www.futureground.monash.edu.au/.

Sevaldson, B. (2005). Developing Digital Design Techniques: Investigations on Creative Design Computing (1st ed.). Oslo: Oslo School of Architecture and Design.

Sevaldson, B. (2008). Rich Design Research Space. FormAkademisk, 1(1), 28-44. Retrieved from https://doi.org/10.7577/formakademisk.119

Sevaldson, B. (2013). Systems Oriented Design: The emergence and development of a designerly approach to address complexity. In J. B. Reitan, P. Lloyd, E. Bohemia, L. M. Nielsen, I. Digranes, \& E. Lutnaes (Eds.), Proceedings of the 2nd International Conference for Design Education Researchers (pp. 17651786). Oslo: ABM-media.

Sevaldson, B. (in preparation). Systems Oriented Design.

Sevaldson, B. (2018). Beyond User Centric Design. In S. Barbero (Ed.), Relating Systems Thinking and Design 2018 Symposium Proceedings: Challenging complexity by Systemic Design towards Sustainability (pp. 516-525). Torino: Systemic Design Association. Retrieved from https://systemic-design.net/wpcontent/uploads/2019/03/6-Sevaldson-def.pdf

Stangeland, S. H. (2018). Gaining by Sharing: A New Comercial Co-Living Model. In W. Unterrainer (Ed.), Emerging Architectures: The Changing Shape of Architectural Practices (1st ed., pp. 06-15). Aarhus: Aarhus School of Architecture.

Sweeting, B. (2016). Design research as a variety of second-order Cybernetic practice. Constructivist Foundations, 11(3), 572-579. Retrieved from https://www.researchgate.net/publication/305317834_Design_Research_as_a_Variety_of_SecondOrder_Cybernetic_Practice

Sweeting, B. (2018). Wicked Problems in Design and Ethics. In P. Jones \& K. Kijima (Eds.), Systemic Design (pp. 119-143). Tokyo: Springer Japan. https://doi.org/10.1007/978-4-431-55639-8_5

Systemic Design. (2018). Systemic Design Association. Retrieved March 27, 2019, from https://systemicdesign.net/sdrn/

Thackara, J. (2015). How to thrive in the next economy: designing tomorrow's world today. London: Thames and Hudson.

Thackara, J. (2019). Bioregioning: Pathways to Urban-Rural Reconnection. She Ji, 5(1), 15-28. https://doi.org/10.1016/j.sheji.2019.01.002

Vogel, G. (2017, May. 10). Where have all the insects gone? Science, 1-4. https://doi.org/10.1126/science.aal1160

Wagler, R. (2017, January). Anthropocene extinction. Access Science. https://doi.org/10.1036/10978542.039350

Wheatley, M. J., \& Frieze, D. (2011). Walk out walk on : a learning journey into communities daring to live the future now (1st ed.). San Francisco: Berrett-Koehler. Retrieved from https://whelprimo.hosted.exlibrisgroup.com/primoexplore/fulldisplay?docid=44CAR_ALMA51125874680002420\&context=L\&vid=44WHELF_CAR_VU 1\&lang=en_US\&search_scope $=$ CSCOP_EVERYTHING\&adaptor=Local Search Engine\&ta $\bar{b}=$ searchall@ $@$ cardiff\&query=any,contains,Margaret Wh 
Zeithaml, V. A., Parasuraman, A., \& Berry, L. L. (1990). Delivering quality service: Balancing customer perceptions and expectations. New York - London: Free Press. Retrieved from https://www.researchgate.net/publication/238685068_Delivering_quality_service_Balancing_customer_p erceptions_and_expectations

\footnotetext{
1 'Environment is the physical and biological surroundings of an organism. The environment covers non-living (abiotic) factors, such as temperature, soil, atmosphere and radiation, and also living(biotic) organisms, such as plants, microorganisms and animals.' (Oxford University Press, 2004).

${ }^{2}$ Biotic refers to either the living or non-living material of biological basis, i.e. tree or wood respectively.

${ }^{3}$ Abiotic refers to material or forces that are not of biological basis, such as stone or wind, respectively.

${ }^{4}$ Research through experimental practice was discussed by Cross as 'praxiology' (Cross, 1999).

${ }^{5}$ This appears through, i.e. airflow, relative humidity or temperature; species such as algae, lichen, butterflies, bumblebees, bats and birds; material properties; or through human trans-disciplinary co-designers, such as the general public, other stakeholders, landscape ecologists, coders, architects, artists and performers, among others.

6 'Ecosystem' was described by Allen and Roberts as an ecological system inside the system that includes the geophysical part (T. F. H. Allen \& Roberts, 1993).

${ }^{7}$ The biosphere is an 'irregularly shaped envelope of the earth's air, water, and land encompassing the heights and depths at which living things exist. The biosphere is a closed and self-regulating system (see ecology), sustained by grand-scale cycles of energy and of materialsin particular, carbon, oxygen, nitrogen, certain minerals, and water. The fundamental recycling processes are photosynthesis, respiration, and the fixing of nitrogen by certain bacteria. Disruption of basic ecological activities in the biosphere can result from pollution.' (Lagasse
} \& Columbia University, 2016)

${ }^{8}$ For example, responsive wood envelopes Ray (see Figure 6) that were designed for semi-interior (Davidová, 2016a, 2017a; Davidová \& Raková, 2018; Davidová, Zatloukal, \& Zímová, 2017) and other breathing spaces (Davidová, 2019b; Davidová \& Prokop, 2018; Davidová \& Zímová, 2018) are responsive through the hygroscopicity of wood cut in tangential section. The prototypes were inhabited by blue stain fungi, algae and lichen. These, namely the algae, are next in the relative humidity and temperature, regulating the moisture content of wood and thus co-causing its warping and therefore breathing. The organisation of algae habitation caused by the material's fibre direction and position within the design is affected by material performance and form. Thus, habitation is organised through its moisture and the organism's abundance and distribution interaction (Davidová, 2017a). The Ray 3 was developed for an application on TreeHuggers (see Figure 8 and Figure 9), responsive insect hotels that moderate a micro-climate based on various species' preferences, thus supporting biodiversity as well as rich edible landscapes for bats and birds (Davidová, 2019b; Davidová \& Prokop, 2018; Davidová \& Zímová, 2017, 2018).

Another example is the COLridor II project (see Figure 7) that uses the hygroscopicity of wood for planting flowers for spring pollinators in an otherwise fully built environment. The outdoors and extensive indoor installation generates micro-biotopes of the edible landscape, covering dwellings and nutrients with opportunities for various species, including, but not limited to, honey-producing plants and local edible and sprouting seeds. These eco-topes create a transition and an exchange in a bio-corridor that connects the central urban with semi-urban areas in the historical city of Třebíč (Davidová, 2019b). The project is in an ongoing co-design with local scouts that have not only built it but also are continuously creatively updating it with various designs of food feeders (see Figure 7).

${ }^{9}$ For example, the TreeHugger prototypes serve as hotels for insects as well as fast-food restaurants for bats and birds (see Figure 8 and Figure 9). The TreeHugger CY was built by the United Nations Buffer Zone - the non-human bio-corridor that is, thanks to the difficult political situation, passing through the otherwise very human oriented urbanised city centre of Nicosia. The prototype questions the linearity and separation of this concept, suggesting its crossing for both the non-human spread to urbanised areas and the human spread of community built iterations on both sides of the city. Therefore, the prototype also interacts and engages with food chains; transfers and exchange of nutrients, such as genetic, biological and biotic as well as abiotic, living and non-living material; cross-species cultural, social and political systems and agencies; and co-habitats and co-dwellings, among others, as discussed above. The integration of the above interacted and engaged systems by the intervening prototypes is here called the eco-system.

${ }^{10}$ For example, the TreeHugger CZ responsive insect hotel that was co-designed and co-built in 2017 is, year by year, increasing its capacity for habitation. Therefore, the production of nutrients in a biotope spot called COLridor I (see Figure 9 and Figure 11) lies in a larger biocorridor (see Figure 13). Its capacity for real-time moderation of a variety of desirable climates over seasons in today's climate extremes clearly shows an adaptive example in the times of climate change and the $6^{\text {th }}$ Mass Extinction. This project exemplifies how to generate architecture that is adaptable and generative in reference and in interaction with its surrounding environment. This project covers not only the natural but also the social, cultural and political environment (see Figure 5 and Figure 9).

${ }^{11}$ Figure 10 shows a traditional variety of breathing screens or walls that enable semi-interior spaces within the architectural non-discrete spatial organisation that offers transitions and, therefore, co-habitation opportunities. These opportunities are therefore engaging crossspecies co-living within a moderated micro-climate and thus also often support the edible landscape through living or non-living biological matter; i.e. pigeon droppings performing as fertilisers in deserted or arid landscapes in politically initiated cave dwellings (Kempe, 1988). A similar discussion on biodiversity, honey production and water security is clear from traditional Scandinavian green roofs with wild blooming species, recently developed into more complex meadow eco-systems through green political and non-profit programs in Europe (Scandinavian Green Infrastructure Association, 2019).

${ }^{12}$ In New Zealand and Australia, rivers bring nutrients (flies) to the bioluminescent larvae of flies of the order Diptera and order Arachnocampa (Plowman, Merritt, \& Fenton, 2013). Vernacularly called 'Glow Worms' specifically appreciate an environment of enclosed caves, as they are bioluminescent and simulate the starry sky, hanging down their sticky wires to catch their prey, such as mosquitos, that are carried with the river (see Figure 12). The caves ensure the wires are not damaged by wind or rain and provide darkness for the thread as well as enclose the space of the prey's exit. Only those caves with flowing water but no streaming ventilation are inhabited by the larvae. These larvae provide their services through their bioluminescent performance to other species, such as humans, in a search for shelter. ${ }^{13}$ The bio-corridors or rivers bringing food, a 'bioregional urbanism' (Thackara, 2019).

${ }^{14}$ For example, the SpiralTreeHouse cultural landscape intervention (see Figure 16) with a self-standing flexible structure that is codesigned for wind and the tree to which it is attached. The platform on the right is co-designed by the habitation of moss, providing comfortable flooring and mattresses for humans and other species, thus extending the present landscape. Its iteration in a semi-urban environment in Slavutych by Chernobyl, Ukraine, the Co-oCo-oNest prototype (see Figure 17) was built, used and re-designed by its users at the same time. The project was developed to bring new futures speculations to the region; although by peoples' world attention abandoned, very rich developing new eco-system that is competitive to other ecological treasures of the world. The aim was to redirect the 
attention to the dead previously glowing past of the local community to the new opportunities of what the today's world issues bring. Therefore, there was placed a QR code, leading to a SAAP blog (Davidová, 2019c) with its recipe for DIY.

Similarly, a QR code was engraved in the TreeHugger CZ insect hotel, leading to a post with a recipe and downloadable Grasshopper code ${ }^{14}$ for its parametric model. To engage the community of makers, the recipe was further advertised in Rhino News (news from the particular software of the parametric model), where every user saw the blog post when starting the software. At Maker Faire Prague 2018 (Kera, 2018), the QR code became a part of its non-anthropocentric refreshment station, next to the human fast food. The station provided seedbombs of blooming species and engaged the community to build a fast food restaurant for bats and birds, the TreeHugger (Davidová, 2019b).

${ }^{15}$ For example, the mapping of Norwegian semi-interior spaces, called svalgangs (see Figure 24), exemplifies that these additions were often built about a hundred years after the initial structures (Berg et al., 2011; Davidová, 2016b; Davidová \& Raková, 2018). Dwellings in Cappadocian caves were constantly rebuilt and adjusted for a variety of purposes and species (see Figure 25) (Davidová \& Uygan, 2017). Another example could be the Maori living village Whakarewarewa, near Rotorua, that is in continuous synergy and change with the local volcanic activity. The thermal performance there is used for daily activities, such as cooking and bathing. However, many houses need to be relocated or are taken, due to the same force (see Figure 23).

${ }^{16}$ Being $\mathrm{n}$ these design processes, this co-design-research represents Sweeting's discussion on what can design research practice give to the second-order cybernetics (Sweeting, 2016). 